\title{
KESETARAAN GENDER: POSISI KEPEMIMPINAN PEREMPUAN DALAM ISLAM
}

\author{
Suhada \\ Sekolah Tinggi Agama Islam (STAI) Alhikmah Jakarta \\ suhada73@yahoo.com
}

\begin{abstract}
ABSTRAK
Tulisan ini bertujuan untuk memaparkan kepemimpinan perempuan dan kesetaraan gender dalam Islam yang sering kali menjadi isu kontroversial dalam masyarakat Islam. Jenis penelitian ini adalah penelitian kepustakaan (library research) dengan pendekatan analisis deskriptif. Sumber data dalam penelitian dibedakan menjadi dua macam, yaitu: primer berupa karya sarjana yang membahasa tentang penafsiran kepemimpinan dan kesetaraan gender dan sekunder berupa buku-buku dan karyakarya ilmiah yang terkait dengan materi penelitian. Penelitian ini menghasilkan kesimpulan bahwa Seorang pemimpin adalah figur yang mengembang tugas fungsional untuk mengawal proses dalam rangka mempengaruhi pikiran, perilaku dan perasaan orang lain, baik kelompok maupun perorangan untuk menuju tujuan bersama. Dalam Islam, dikenal beberapa prinsip kepemimpinan, yaitu: tanggung jawab, tauhid, musyawarah, dan adil. Kepemimpinan perempuan seringkali menjadi isu kontroversial dalam masyarakat Islam, ada yang mendukung dan ada juga yang menolak. Semntara itu, dalam perspektif kesetaran gender, terdapat keyakinan bahwa agama Islam tidak meletakkan antara hak dan kewajiban yang ada pada anatomi manusia dalam posisi yang saling berlawanan, hak dan kewajiban itu selalu setara di mata Islam untuk kedua jenis kelamin yang berbeda tersebut. Islam menjunjung tinggi konsep keadilan untuk siapapun tanpa melihat jenis kelamin mereka. Islam merupakan agama yang terdepan dalam usaha membebaskan belenggu tirani perbudakan, kesetaraan hak dan tidak pernah memberikan prestise salah satu jenis kelamin saja. Islam lahir sebagai agama yang menebar kasih dan sayang bagi siapa saja.
\end{abstract}

Keyword: Kemimpinan Wanita, Kesetaraan Gender, Ketidakadilan Gender

\begin{abstract}
ABSTRACK
This paper aims to describe women's leadership and gender equality in Islam which is often a controversial issue in Islamic societies. This type of research is library research with a descriptive analysis approach. Sources of data in research can be divided into two types, namely: primary in the form of undergraduate work that discusses the interpretation of leadership and gender equality and secondary in the form of books and scientific works related to research material. This research concludes that a leader is a figure who develops a functional task to oversee the process in order to influence the thoughts, behavior and feelings of others, both groups and individuals towards a common goal. In Islam, there are several principles of leadership, namely: responsibility, monotheism, deliberation, and fairness. Women's leadership is often a controversial issue in Islamic societies, some support and some refuse. Meanwhile, in the perspective of gender equality, there is a belief that Islamic religion does not place rights and obligations in human anatomy in opposing positions, rights and obligations are always equal in the eyes of Islam for the two different sexes. Islam upholds the concept of justice for anyone regardless of their gender. Islam is the foremost religion in the effort to free the bondage of tyranny of slavery, equality of rights and never give the prestige of only one sex. Islam was born as a religion that spreads love and affection for anyone.
\end{abstract}

Keyword: Women's Leadership, Gender Equality, Gender Injustice 


\section{PENDAHULUAN}

Isu yang senantiasa menjadi kontroversi dalam ranah publik Islam adalah boleh tidaknya wanita menjadi pempimpin. Diskursus kepemimpinan wanita dalam ranah publik mempunyai keberagaman dan kompleksitas dibandingkan dengan diskusi kepemimpinan wanita di ranah domestik atau rumah tangga.

Abbas Mahmud al-Aqqad merupakan salah satu sarjana Islam yang menolak keras wanita menjadi pemimpin. Hal ini dikarenakan adanya perbedaan fisik dan biologis menjadi prasyarat kualifikasi manusia yang dapat mengemban tanggung jawab sosial. Perbedaan jenis kelamin, juga berakibat munculnya perbedaan tanggung jawab sosial, laki-laki bertanggung jawa dalam ranah publik sedangkan wanita bertanggung jawab menjaga keharmonisan ranah domestik. Al-Aqqad mengemukakan bahwa hak menjadi pemimpin dilandaskan pada kemampuan dan kesanggupan alamiah yang cenderung dimiliki oleh lakilaki dan bukan wanita. Bahkan, menurut al-Aqqad wilayah kepemimpinan wanita adalah sebatas wilayah rumah tangga, sementara laki-laki seluas perjalanan hidup. ${ }^{1}$

Tesis al-Aqqad tentang kepemimpinan wanita tersebut di atas mendapatkan antitesis dalam "ijtihad" Nasaruddin Umar, bahwa tidak ada satupun dalil dalam al-Qur'an maupun hadis yang melarang kaum wanita terjun aktif dalam kancah perpolitikan. Tentunya, hal ini dapat dijadikan sebagai landasan hukum atas hak yang dimiliki oleh wanita untuk aktif dalam bidang percaturan politik, baik sebagai pejabat maupun kepala negara. Lebih lanjut, Nasaruddin Umar menunjukkan bahwa term khalifah dalam QS. Al-Baqarah [2]: 30 tidak mereferensikan satu jenis kelamin saja. Oleh karena itu, laki-laki dan wanita mempunyai fungsi yang sama sebagai pemimpin yang akan mempertanggungjawabkannya kepada Allah SWT. $^{2}$

Pendapat Nasaruddin Umar tersebut di atas, senada dengan pernyataan Husein Muhammad. Husein Muhammad merumuskan pendapatnya dengan terlebih dahulu "melacak" argumentasi-argumentasi sarjana Islam klasik yang menutup rapat "ruang" wanita untuk menjadi pemimpin di ranah publik. Kemudian, Husein Muhammad mendedarkan perkembangan sosial pada awal abad ke-20 yang mulai responsif terhadap keadaan wanita terutama pada aspek pendidikan. Hal ini pada gilirannya membukan akses wanita untuk terjun dalam dunia politik. Terlebih adanya perubahan undang-undang di negara-negara Islam, seperti: Mesir, Sudan, Tunisia, Irak dan Yordania yang mengakomodasi partisipasi wanita dalam ranah publik. ${ }^{3}$

Menurut Kaukab Siddique kepemimpinan Aisyah dalam perang Jamal tidak terjadi secara tiba-tiba tetapi melalui proses yang panjang. Hal ini terbukti pada masa awal Islam, Aisyah merupakan sosok wanita yang sering kali dimintai fatwa oleh para sahabat Nabi Muhammad SAW, seperti: Abu Bakar, Utsman ibn Affan dan Uman ibn al-Khattab. Sebelum menjadi pemimpin perang Jamal, Aisyah sudah menjelma sebagai mufti wanita yang fatwa-fatwanya diterima oleh kalangan sahabat baik laki-laki maupun wanita. Maka, tidak mengherankan jika orang-orang dari penjuru semenanjung Arabia mendatangi Aisyah yang terkenal cerdas untuk belajar ilmu agama Islam. Bahkan, tidak sedikit ulama yang terkenal pada masa itu pernah menimba ilmu pengatahuan dari Aisyah. ${ }^{4}$ Dengan demikian, figur Aisyah r.a yang menjadi panglima perang Jamal dan mufti dari kalangan sahabat merupakan bukti bahwa seorang wanita dapat menjadi pemimpin di ranah publik.

${ }^{1}$ Abbas Mahmud al-Aqqad, Filsafat al-Qur'an: Filsafat, Spiritual dan Sosial dalam Isyarat al-Qur'an, (Jakarta: Pustaka Firdaus, 1986), h. 74-75.

${ }^{2}$ Nasaruddin Umar, Kodrat Perempuan dalam al-Qur'an, (Jakarta: Fikahati Aneka, 2000), h. 49.

${ }^{3}$ Husein Muhammad, Islam Agama Ramah Perempuan: Pembelaan Kiai Pesantren, (Yogyakarta: LkiS, 2004), h. 170-172.

${ }^{4}$ Kaukab Siddique, Menggugat Tuhan Yang Maha Maskulin, terj. Arif Maftuhin, (Jakarta: Paramadina, 2012), h. 50-53. 
Lebih lanjut, Abdurrahman Wahid memberikan ruang pada wanita untuk menjadi pemimpin. Kesuksesan kepemimpinan seorang wanita sangat bergantung pada penerimaan laki-laki yang berada di bawah kepemimpinannya. Abdurrahman Wahid berpendapat bahwa pandangan ulama yang menganggap wanita adalah makhluk yang lemah dibandingkan dengan laki-laki sehingga tidak mempunyai kecakapan dalam memimpin bertolak belakang dengan fakta sejarah yang terjadi. Dalam sejarah, tercatat beberapa wanita menjadi pemimpin suatu negara, misalnya: Ratu Balqis, Cleopatra, Margaret Theatcher, Benazir Butho dan Corie Aquino. Bahkan, Abdurrahman Wahid mengakui kemampuan Megawati Soekarnoputri untuk menjadi presiden. ${ }^{5}$

\section{TINJAUAN PUSTAKA}

Dalam pandangan Ibn Khaldun $^{6}$ dan al-Mawardi ${ }^{7}$, adanya seorang pemimpin dalam suatu kelompok merupakan kewajiban. Seorang pemimpin dalam "bingkai" kepemimpinan adalah figur yang mengembang tugas fungsional untuk "mengawal" proses dalam rangka mempengaruhi pikiran, perilaku dan perasaan orang lain, baik kelompok maupun perorangan untuk menuju tujuan bersama. ${ }^{8}$ Dengan demikian, kehadiran kepemimpinan adalah untuk menjaga dinamika perkembangan suatu masyarakat agar tetap pada jalur menuju tujuan bersama yang ingin dicapai.

Sutarto Wijono mengutip Griffin dan Ebert mengatakan bahwa kepemimpinan (leadership) merupakan rangkaian proses yang dilakukan untuk mempengaruhi orang lain. ${ }^{9}$ A. M. Mangunhardjana berpendapat, inti dari kepemimpinan terletak pada fungsi atau tugas. Tugas kepemimpinan adalah pengabdian untuk melayani masyarakat dalam menyelesaikan masalah-masalah yang dihadapi demi tercapainya tujuan dan cita-cita yang telah ditetapkan bersama. ${ }^{10}$ Kepemimpinan yang baik menurut Syaiful Sagala adalah kepemimpinan efektif yang menginspirasi dan memenangkan komitmen. ${ }^{11}$

Definisi kepemimpinan menurut Ayub Ranoh berbeda dengan otoritas. Kepemimpinan lebih condong kepada fungsi dan peran dalam memberikan pengaruh, sementara otoritas lebih cenderung kepada makna dasar dan hak yang absyah dan disertai persyaratan adanya pengakuan orang-orang yang mengalami otoritas tersebut, baik dalam platform tradisi, legalitas, maupun kualitas istimewa yang melekat pada seorang pemimpin. $^{12}$

Salah satu ayat dalam al-Qur'an yang menjelaskan tentang kepemimpinan adalah QS. Al-Baqarah: 30.

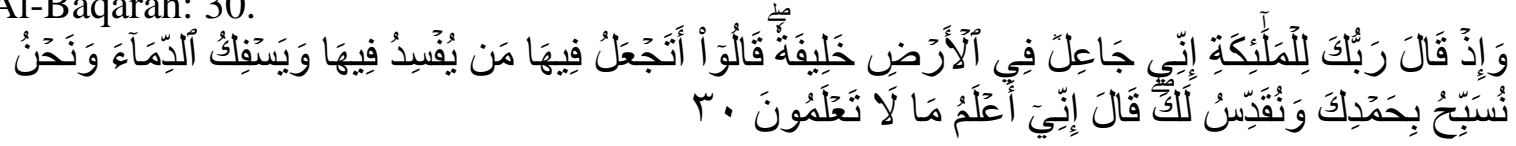

Artinya: "Ingatlah ketika Tuhanmu berfirman kepada para Malaikat:

"Sesungguhnya aku hendak menjadikan seorang khalifah di muka bumi." mereka berkata: "Mengapa Engkau hendak menjadikan (khalifah) di bumi itu orang yang akan

${ }^{5}$ M.N. Ibad, Kekuatan Perempuan dalam Perjuangan Gus Dur-Gus Miek,(Yogyakarta: Pustaka Pesantren, 2011), h. 101-102.

${ }^{6}$ Abd al-Rahman Ibn Khaldun, Muqaddimah, (Mesir: Maktabah Mustafa Muhammad, t.t), h. 190.

${ }^{7}$ Abu al-Hasan Ali ibn Muhammad ibn Habib al-Bashri al-Baghdadi, Al-Ahkam al-Sulthaniyyah wa alWilayat al-Diniyyat (Beirut: Dar al-Kutub al-Ilmiyyah, 2006), h. 5.

${ }^{8}$ Khatib Pahlawan Karyo, Kepemimpinan Islam dan Dakwah (Jakarta: Amzah, 2005), h. 9.

${ }^{9}$ Sutarto Wijono, Kepemimpinan dalam Perspektif Organisasi (Jakarta: PRENADAMEDIA GROUP, 2018), h. 1.

${ }^{10}$ A. M. Mangunhardjana, Kepemimpinan, (Yogyakarta: Kanisius, 1976), h. 12.

${ }^{11}$ Syaiful Sagala, Pendekatan dan Model Kepemimpinan, ( Jakarta: PRENADAMEDIA GROUP, 2018), h. 1.

${ }^{12}$ Ayub Ranoh, Kepemimpinan Kharismatis: Tinjauan Teologis-Etis atas Kepemimpinan Kharismatis Sukarno, (Jakarta: PT BPK Gunung Mulia, 2006), h. 72. 
membuat kerusakan padanya dan menumpahkan darah, Padahal Kami Senantiasa bertasbih dengan memuji Engkau dan mensucikan Engkau?" Tuhan berfirman: "Sesungguhnya aku mengetahui apa yang tidak kamu ketahui."

Muhammad Rasyîd Ridhâ, menafsirkan kata khalîfah, yaitu manusia merupakan

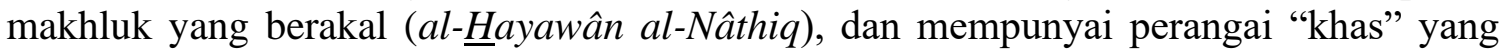
tidak dimiliki oleh makhluk lain. Sehingga, Allah SWT menurunkan syariat dan hukumNya, kepada manusia yang berdisposisi sebagai khalifah-Nya di bumi, melalui mekanisme akal dan wahyu. ${ }^{13}$ Dalam hal ini, Fazlur Rahman menambahkan, bahwa manusia tercipta dari elemen materi dan non materi, mempunyai superioritas pengetahuan yang diakui oleh para malaikat, yang menunjukkan keunggulan manusia dibandingkan makhluk lain, seperti malaikat dan iblis. ${ }^{14}$

Dengan demikian, kemampuan manusia dalam menalar sesuatu melalui potensi akal yang "superior" perlu dikembangkan melalui pendidikan holistik yang berdimensi fitrah, agar manusia bisa mengemban tugas sebagai khalifah Allah di muka bumi, dan tidak sebaliknya "menumpahkan" darah dan membuat kerusakan di bumi.

Dalam pandangan Harun Nasution, hakekat manusia perspektif Islam mempunyai dua unsur, materi yaitu tubuh yang mempunyai hayyat dan unsur non-materi yaitu ruh yang mempunyai dua adaya yaitu daya rasa di dada dan daya pikir di kepala. ${ }^{15}$ 'Âisyah bint Syâthi' mengkatagorisasikan penyebutan manusia di dalam al-Qur'an menjadi tiga macam, basyar, insân dan al-Nâs, di man ketiganya mempunyau makna yang berbeda. Basyar, disebut 27 kali dalam al-Qur'an. ${ }^{16}$ Secara tematis, al-Qur'an menyebut manusia sebagai basyar untuk mengindikasikan manusia sebagai makhluk biologis. Basyar, mempunyai pengertian etimologis penampakan sesuatu yang indah dan kulit, ${ }^{17}$ "petanda" bahwa manusia mempunyai kulit yang tidak terlihat secara jelas, hal ini, membedakan manusia dengan kera, sapi, kuda ayam dan lain sebagainya. Oleh karena itu, basyar mereferensikan manusia dalam aspek biologis dengan sifat-sifat biologis, seperti makan, minum dan seks.

Al-Qur'an menyebut kata insân, digunakan untuk menunjukkan manusia sebagai makhluk yang bisa mengoptimalkan kemampuan akalnya, dalam aktualisasi kehidupan nyata. Lebih lanjut, Insân merupakan "makhluk" yang bisa membuat perencenaan, menimbang baik dan buruk, kegiatan yang dilakukannya memanfaatkan kapasitas akal. ${ }^{18}$ Jalaludin Rahmat menambahkan, al-Qur'an menyebutkan kata insân dalam tiga konteks. Pertama, menunjukkan keistimewaan manusia sebagai khalifah dan pemikul amanah. Kedua, dihubungkan dengan predisposisi negative dari manusia. Ketiga, konteks proses penciptaan manusia. ${ }^{19}$ Manusia dalam konteks sebagai khalifah dan pemikul amanah manusia dianugerahi ilmu pengetahuan, diberi kemampuan discovery dan menguasai hukum alam. Dengan demikian, pada pundak manusia terdapat tanggung jawab untuk menjaganya. ${ }^{20}$

\footnotetext{
${ }^{13}$ Muhammad Rasyîd Ridhâ, Al-Tafsîr al-Manâr, juz 1, h. 258-259.

${ }^{14}$ Fazlur Rahman, Major Themes of The Qur'ân, h. 21.

${ }^{15}$ Harun Nasution, Filsafat dan Mistisme Dalam Islam, (Jakarta: Bulan Bintang, 1987), h. 36.

${ }^{16}$ Muhammad Fu'ad 'Abd al-Bâqî, Al-Mu'jam al Mufahras li al-Fazh al-Qur'ân al-Karîm, (Beirut: Dar

${ }^{17}$ Quraisy Shihab, Wawasan Al Qur'an, (Bandung: Mizan, 1998), h. 278.

${ }^{18}$ Musa Asy'arie, Manusia Pembentuk Kebudayaan dalam Al Qur'an, (Yogyakarta: LESFI, 1992), h.

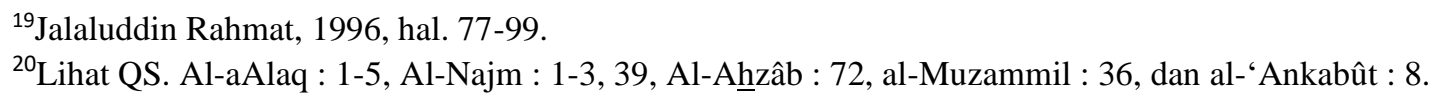
al-Fikr, 1407 H), h. 119. 30. 
Adapun dalam konteks penciptaan manusia insan dan basyar dinisbahkan sekaligus, yakni diciptakan dari tanah liat, sari pati tanah. ${ }^{21}$ Pada konteks insân yang sebagai petanda predisposisi negative manusia, manusia digambarkan mempunyai kecenderungan berbuat aniyaya dan ingkar, tergesa-gesa, kikir, bodoh, suka membantah dan berdebat, dan lain sebagainya. ${ }^{22}$

Kata al-Nâs, digunakan untuk menunjukkan dimensi sosial manusia di dalam kelompok masyarakat. Manusia adalah makhluk bebas, tetapi kebebasan manusia adalah "bebas untuk" bukan "bebas dari”. Dalam konteks ini, 'Ibn 'Abî Zamanîn, berpendapat, sebagai makhluk sosial manusia agar senantiasa memohon perlindungan kepada Allah SWT, agar terhindar dari godaan setan yang bersemayam di dalam diri manusia, dan bisa mengakibatkan ekses negatif di dalam kehidupan sosial mereka. ${ }^{23}$

Al-Gazâlî memaparkan bahwa secara filosofis, manusia mempunyai totalitas dalam memikirkan eksistensi, hakikat, pengetahuan, tindakan, hingga wujudnya sendiri. ${ }^{24} \mathrm{Hal}$ ini, mengingat, potensi manusia melekat di dalam piranti yang disematkan di dalam penciptaan manusia sebagai khalifat fi al-Ard berupa: qalb ${ }^{25}$, fuad ${ }^{26}$, hawa $^{27}$, $n a f s^{28}, r u \hat{h} \underline{h}^{29}$, dan 'aql $l^{30}$. Piranti-piranti tersebut "menobatkan" manusia sebagai ciptaan

${ }^{21}$ Fazlur Rahman, Major Themes of The Qur'ân, (Chicago: The University of Chicago Press, 2009), h. 21.

${ }^{22}$ Amie Primarni dan Khairunnas, Pendidikan Holistik: Format Baru Pendidikan Islam Membentuk Karakter Paripurna, (Jakarta: Al-Mawardi Prima, 2013), h. 110.

23،Abû 'Abdullâh ibn 'Abdullâh ibn 'Abû Zamanîn, Tafsîr al-Qur'ân al-'Azhîm, (T.tp: Al-Fârûq alHadîtsah, 2002), jilid 5, h. 175.

${ }^{24}$ Abidin ibnu Rusn, Pemikiran Al Ghazali Tentang Pendidikan, (Yogyakarta: Pustaka Pelajar, 1998), Cet 1, h. 30 .

${ }^{25}$ Kata qalb, di dalam al-Qur'an salah satunya termuat dalam QS. Al-Syuarâ': 89, disandingkan dengan kata salîm. Dalam hal ini, Ibn Katsîr, menginventarisir beberapa riwayat dari sahabat untuk menafsirkan frasa qalb salîm. Pertama, Muhammad ibn Sirîn, bahwa qalb salîm mempunyai makna kemampuan manusia untuk mengetahui bahwa Allah adalah haq, hari kiamat pasti datang, dan bahwa Allah lah yang akan membangkitkan manusia dari kubur. Kedua, Ibn 'Abbâs, bahwa qalb salîm adalah senantiasa manusia hidup dalam naungan kalimat syahadah. Ketiga, Mujâhid dan al-Hasan, qalb salîm terbebas dari kemusyrikan. Lihat 'Imâd al-Dîn 'Abî al-Fidâ' 'Ismâ'îl al-Dimasyqî, Tafsîr al-Qur'ân al- 'Azhîm, (Mesir, Mu'assasah Qurthubah, t.t), jilid, 10, h. 355. Dengan demikian, qalb, merupakan piranti yang di dalamnya terdapat potensi manusia untuk mengarahkan segala pengetahuannnya untuk menuju kehidupan yang terbebas dari kemusyrikan dengan cara tetap berpegang teguh kepada kalimat syahadah, dan mempercayai bahwa Allah itu maha benar, hari kiamat pasti datang, dan setiap manusia yang telah masuk alam kubur akan dibangkitkan kembali oleh Allah. Sehingga, qalb, sendiri pada akhirnya berhak menyandang gelar qalb salîm.

${ }^{26}$ Kata $f u$ 'ad, terdapat dalam QS. Hûd: 120. Al-Zamakhsarî, menafsirkan kata fu'ad sebagai sarana untuk keyakinan bertambah dan suasana ketenangan hati. Hal ini dikarenakan, semakin banyak argumentasi yang ada, maka akan semakin menambah ketetapan hati dan penerimaan ilmu pengetahuan. Lihat Abû al-Qâsim Mahmûd ibn 'Umar al-Zamakhsyarî, Al-Kasysyâf 'an Gawâmizh al-Tanzîl wa 'Uyûn al-'Aqâwîl fî̀ Wujûh alTa’wîl, (Riyad: Maktabah al-'Abîkân, 1998), juz 3, h. 248.

${ }^{27}$ Kata $\underline{h} a w \hat{a}$, di antaranya terdapat di dalam QS. Thahâ: 81. Al-Marâgî menafsirkan kata tersebut sebagai kecenderungan yang membawa manusia kepada kehancuran dan kejatuhan. Lihat 'A hmad Mushthafâ al-Marâgî, Tafsîr al-Marâgî, (Mesir: T.tp, 1946), juz 16, h. 136.

${ }^{28}$ Kata nafs, salah satunya terdapat dalam QS. Yûsuf: 53. Ibn 'Âsyûr menafsirkan kata nafs QS. Yûsuf: 53, terkait dengan dalam konteks kekaguman raja terhadapn pribadi Nabi Yûsuf, yang sangat tabah dan sabar dalam menghadapi cobaan dan kesulitan, serta ilmu dan hikmat yang dimilikinya sangatlah luas. Lihat Muhammad Thâhir ibn 'Âsyûr, Tafsîr al-Tahrî̀r wa al-Tanwîr, (Tûnis: Al-Dâr al-Tûnisiyyah, 1984), juz 13, h. 7.

${ }^{29}$ Kata $r u \hat{h}$, di antaranya terdapat dalam QS. Al-Mu'min: 15. Jalâl al-Dîn al-Mahahallî dan Jalâl al-Dîn al-Suyûthi, menafsikan kata rûh dalam QS. Al-Mu'min: 15, sebagai malaikat penyampai wahyu atau malaikat Jibril. Lihat Jalâl al-Dîn Muhammadi ibn 'Aḥmad al-Mahallî dan Jalâl al-Dîn 'Abd al-Rahmân ibn 'Abî Bakar al-Suyûthî, Tafsîr al-Qur'ân al- 'Azhîm li al-Imâm al-Jalailain, (Surabaya: Dâr al-'Abidîn, tt), juz 2, h. 148. 
Allah SWT yang mempunyai potensi kemakhlukan yang paling baik, mulia, cerdas dan pandai, serta mendapatkan amanah untuk mengemban tugas dan memperoleh kasih sayang Allah SWT yang sempurna. ${ }^{31}$

Dengan tugas yang Allah SWT bebankan kepada manusia, menunjukkan bahwa manusia adalah makhluk yang diciptakan untuk menjalankan misi kepemimpinan di bumi sebagai wujud amanah dan Tuhan Yang Maha Menciptakan. Dalam ranah kehidupan sosial, masyarakat tidak dapat dipisahkan dari kepemimpinan. ${ }^{32}$ Kepemimpinan sangat penting dalam setiap lini kehidupan manusia mulai lingkungan keluarga, tempat kerja dan aktivitas manusia dalam lingkungan sosial tempat tinggal mereka. ${ }^{33}$

Sejatinya, kepemimpinan adalah ilmu, seni dan profesi. Wujud kepemimpinan sebagai ilmu dapat dipelajari, namun implementasinya harus disesuaikan dengan keadaan atau realitas kehidupan yang dihadapi. Seseorang yang menguasai seni kepemimpinan adalah mereka yang mempunyai kecakapan teknis dalam memberikan instruksi, anjuran, teguran, pengertian, menerika kritik dan saran, serta mampu memperkuat identitas komuniras yang dipimpin, memberikan bantuan adaptasi untuk anggota baru, dan mencegah terjadinya hal-hal buruk untuk kelompok yang dipimpinnya. ${ }^{34}$

Menurut beberapa sarjana, kepemimpinan dalam Islam mempunyai beberapa prinsip, yaitu:

1) Prinsip Tanggung Jawab

Ajaran Islam menyatakan bahwa setiap manusia adalah pemimpin dan akan dimintai pertanggungjawaban. Tanggungjawab merupakan esensi mendasar yang harus diketahui terlebih dahulu oleh setiap orang yang mencalonkan diri sebagai pemimpin untuk menjaga amanah dan kepercayaan yang telah diberikan rakyat agar tidak sia-sia. ${ }^{35} \mathrm{Hal}$ ini dijelaskan dalam QS. Al-Nisa' [4]: 58.

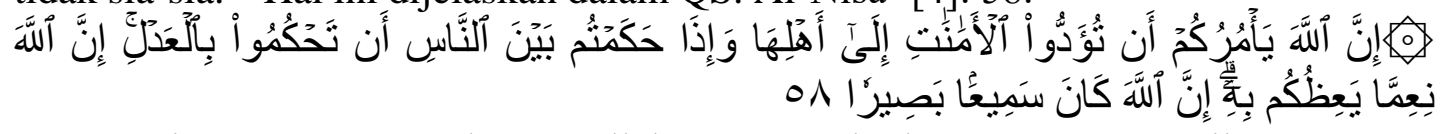

Artinya: "Sesungguhnya Allah menyuruh kamu menyampaikan amanat kepada yang berhak menerimanya, dan (menyuruh kamu) apabila menetapkan hukum di antara manusia supaya kamu menetapkan dengan adil. Sesungguhnya Allah memberi pengajaran yang sebaik-baiknya kepadamu. Sesungguhnya Allah adalah Maha Mendengar lagi Maha Melihat".

2) Prinsip Tauhid

${ }^{30}$ Kata 'aql, di antaranya terdapat dalam QS. Al-Anfâl: 22. Al-Thabarî menafsirkan kata 'aql dalam konteks QS. Al-Anfâl: 22, sebagai potensi manusia untuk memikirkan berpikir sehingga bisa mengetahui perintah dan larangang Allah, kemudian melaksanakan perintah dan meninggalkan larangan Allah. Lihat 'Abû Ja'far Muhammad ibn Jarîr al-Thabarî, Tafsîr al-Thabarî, (Kairo: Maktabah Ibn Taimiyyah, t.t), juz 13, h. 459. Lebih lanjut, menarik untuk sedikit mengulas tentang akal (reason) dan wahyu (revelation), sebagaimana dipaparkan oleh oleh A.J. Arberry. Menurut Arberry, diskursus tentang hubungan akal dengan wahyu sudah terjadi lama dalam sejarah pemikiran manusia. A. J. Arbcrry, Revelation and Reason in Islam, (London: George Allen \&Unwin Ltd., 1975), h. 7. Hal ini, merupakan problem filosofis yang dialami oleh umat manusia, tidak terkecuali umat Islam. Sebagai contoh, aliran Mu'tazilah mengenalkan dua metode berpikir silogisme dan analogi. Lihat Wolfson, Harry Austryn, The Philosophy Kalâm, (Harvard: Harvard University Press, 1976) h. 30 .

${ }^{31}$ Rachmat Ramadhana al-Banjari, Prophetic Leadership, (Yogyakarta: DIVA Press, 2008), h.21.

${ }^{32}$ Veithzal Rivai dan Arvian Arifin, Islamic Leadership: Membangun Super Leadership Melalui Kecerdasan Spiritual, (Jakarta: Bumi Aksara, 2009), 142-143.

${ }^{33}$ Soedarsono Martoprawiro, Kepemimpinan, (Jakarta: Mutiara, 1980), h. 9.

${ }^{34}$ Soedarsono Martoprawiro, Kepemimpinan, h. 9-10.

${ }^{35}$ Veitzal Rivai, Kiat Memimpin Abad ke-21, (Jakarta: Raja Grafindo, 2004), h. 16. 
Agama Islam menyerukan kepada manusia untuk menuju kepada arah kesatuan akidah yang dapat diterima oleh semua golongan, yaitu tauhid. ${ }^{36} \mathrm{Hal}$ tersebut dijelaskan dalam QS. Al-Anbiya' [21] : 92

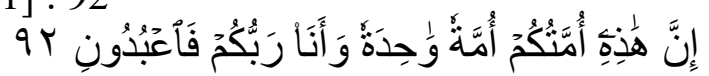

Artinya: "Sesungguhnya (agama Tauhid) ini adalah agama kamu semua; agama yang satu dan Aku adalah Tuhanmu, maka sembahlah Aku".

3) Prinsip Musyawarah

Perintah kepada pemimpin untuk melaksanakan musyarawah terdapat di dalam al-Qur'an, bahwa seorang pemimpin wajib melakukan musyawarah dengan orang-orang yang mempunyai pengetahuan dan berpandangan baik. ${ }^{37}$

Firman Allah SWT dalam QS. Al-Syura [41]: 38

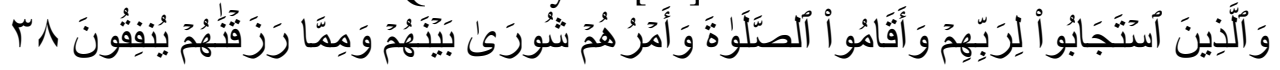

Artinya: "Dan (bagi) orang-orang yang menerima (mematuhi) seruan Tuhannya dan mendirikan shalat, sedang urusan mereka (diputuskan) dengan musyawarat antara mereka; dan mereka menafkahkan sebagian dari rezeki yang Kami berikan kepada mereka".

Dalam pandangan Al-Qâsimî (w. 1914 M), QS. Al-Syura [42]: 38 mengandung ajaran untuk tidak memutuskan suatu permasalahan tanpa melakukan musyawarah terlebih dahulu. ${ }^{38}$ Al-Tabarî (w. $310 \mathrm{H}$ ) menambahkan bahwa musyarawah penting dilakukan ketika masyarakat terbagi ke dalam beberapa golongan. ${ }^{39}$ Dengan mengutip al-Khatib di dalam riwayat Mâlik, al-Suyûtîn (w. $911 \mathrm{H}$ ) menginformasikan bahwa musyawarah merupakan perintah yang turun setelah Nabi Muhammad SAW dan belum pernah turun di dalam al-Qur'an. Musyawarah adalah berkumpulnya para ahli ibadah (al-'Âbidûn) dari umat Islam untuk memecahkan masalah bersama-sama dan tidak secara sendirian dalam memutuskan penyelasaian masalah tersebut. ${ }^{40}$ Dengan demikian, seorang pemimpin yang baik adalah orang yang tidak serta merta memutuskan penyelesaian dengan pertimbangan akal sendiri, namun mengajak orang-orang yang berilmu dan berpandangan luas untuk bermusyawarah dalam rangka mencari solusi terbaik suatu masalah.

4) Prinsip Adil

Dalam suatu masyarakat "pancaran" keadilan dari seorang pemimpin mempunyai posisi yang sangat penting. Keadilan merupakan suatu "rumusan" perlakuan seorang pemimpin terhadap untuk tidak membeda-bedakan, memihak, berat sebelah dalam melayani kepentingan masyarakat. Hal ini dijelaskan dalam QS. AlMaidah [5]: 8 berikut ini:

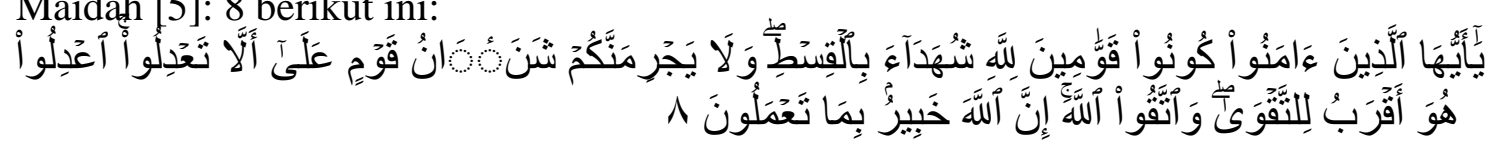

Artinya: "Hai orang-orang yang beriman hendaklah kamu jadi orang-orang yang selalu menegakkan (kebenaran) karena Allah, menjadi saksi dengan adil. Dan janganlah sekali-kali kebencianmu terhadap sesuatu kaum, mendorong kamu untuk berlaku tidak adil. Berlaku adillah, karena adil itu lebih dekat kepada takwa. Dan

\footnotetext{
${ }^{36}$ Muhtadi Zainuddin dan Abd Mustaqim, Studi Kepemimpinan Islam: Telaah Normatif dan Historis, (Semarang: Putra Mediatama Press, 2005), h. 58.

${ }^{37}$ Veitzal Rivai, Kiat Memimpin Abad ke-21, h. 7.

${ }^{38}$ Muhammad Jamâl al-Dîn al-Qâsimî, Tafsîr al-Qâsimî al-Musammâ Mahasin al-Ta'wîl, (Bairut: Dâr al-Kutub al-'Ilmiyyah, 2003), juz 8, h. 372.

39،Abû Ja'far Muhammad ibn Jarîr al-Tabarî, Tafsîr al-Tabarî: Jâmi' al-Bayân 'an Ta'wîl âyi alQur'ân, (Kairo: Maktabah Ibn Taimiyyah, t.t), juz 20, h. 523.

${ }^{40}$ Jalâl al-Dîn al-Suyûtîi, Al-Dûr al-Mantsûr fî al-Tafsîr bi al-Ma'tsûr, (Kairo: Markaz Hajr li al-Buhûts wa al-Dirâsât al-‘Arabiyyah wa al-'Islâmiyyah, 2003), juz 13, h. 168.
} 
bertakwalah kepada Allah, sesungguhnya Allah Maha Mengetahui apa yang kamu kerjakan".

Ibn Katsîr (w. 774 H), menyatakan salah satu kandungan dari QS. Al-Maidah [5]: 8 adalah larangan menebar kebencian dalam masyarakat dengan meninggalkan keadilan, namun harus menegakkan keadilan baik kepada kawan atau lawan karena keadilan adalah "sarana" yang mendekatkan pada ketakwaan. ${ }^{41}$ Al-Baghawî (w. 516 H) menyatakan berperilaku dan berkata dengan penuh keadilan karena Allah SWT (kûnû qawwâmîna lillâh) kepada kawan dalan lawan adalah "identitas" orang-orang yang beriman. ${ }^{42}$ Bahkan, menurut 'Abû Hayyân al-'Andalusî (w. 745 H) keadilan adalah penopang bagi "bersemai"nya cinta kepada sesama. ${ }^{43}$ Dengan demikian, penegakkan keadilan ditengah kehidupan masyarakat adalah suatu keniscayaan yang tidak boleh ditinggalkan. Pemimpin sejati adalah orang yang selalu menebar kecintaan kepada semua lapisan masyarakat dengan menegakkan keadilan setinggitingginya, dan sebaliknya membenamkan kebencian sedalam-dalamnya.

\section{METODE}

Penelitian ini menggunakan pendekatan kualitatif dengan bertitik tolak pada analisis data deskriptif berupa kata-kata tertulis atau lisan dari orang-orang dan perilaku yang diamati. ${ }^{44}$ Adapun jenis penelitian yang digunakan oleh penulis adalah penelitian kepustakaan (library research) dengan menelaah buku-buku yang berkaitan dengan pokok-pokok permasalahan dari analisis literatur ini dihasilkan data yang dikehendaki untuk ditelaah secara mendalam. ${ }^{45}$

Dalam penelitian ini, sumber data yang penulis gunakan ada dua macam, yaitu: data primer merupakan data yang hanya bisa didapatkan dari sumber otentik (asli) atau pertama ${ }^{46}$ serta data sekunder yang merupakan sumber data yang mempunyai kegunaan untuk mendukung dan memberikan informasi tambahan kepada data primer.

Teknik pengumpulan data baik primer maupun sekunder dilakukan dengan membaca, memahami, mengidentifikasi, menganalisis dan membandingkan data yang satu dengan data lainnya yang terdapat dalam sumber data. Setelah data terhimpun, kemudian diklasifikasikan sesuai dengan sifat dalam bab-bab tertentu supaya mempermudah analisis. ${ }^{47}$ Adapun dalam penelitian ini, penulis mengumpulkan data dengan membaca, memahami, mengidentifikasi, menganalisis, dan membandingkat teori-teori yang berkaitan dengan kepemimpinan wanita.

Berdasarkan tujuan penelitian yang ingin dicapai, maka teknik analisis data yang penulis gunakan dalam penelitian ini adalah deskriptif dengan tujuan untuk memberikan gambaran tentang subyek penelitian berdasarkan data dari sumber penelitian yang diperoleh dari kelompok subyek yang diteliti dan tidak dimaksudkan pengujian hipotesis. ${ }^{48}$

41'Imâd al-Dîn 'Abû al-Fidâ' 'Ismâ’il ibn Katsîr al-Dimasyqî, Tafsîr al-Qur'ân al- 'Azîm, jilid 5, h. 128.

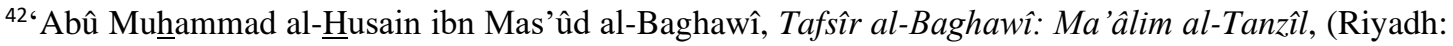
Dar Thayyibah li al-Nasyar wa al-Tawzi', 1409 H), jilid 3, h. 27.

43، Abû Hayyan al-‘Andalusî, Tafsîr al-Bahrr al-Muhît, (Beirut: Dâr al-Kutub al-'Ilmiyyah, 1993), juz 3, h. 455 .

\footnotetext{
${ }^{44}$ Lexy J. Moeloeng, Metodologi Penelitian Kualitatif (Bandung: Remaja Rosdakarya. 2001), h. 3.

${ }^{45}$ Moh. Nasir, Metode Penelitian (Jakarta: Bumi Aksara, 2000), h. 213.

${ }^{46}$ Jonathan Sarwono, Metodologi Penelitan Kuantitatif dan Kualitatif (Yogyakarta: Graha Ilmu, 2006),

${ }^{47}$ Winarno Surahmah, Metode Penelitian Survey (Jakarta: LP3S, 1993), h. 139.

${ }^{48}$ Saefudin Anwar, Metodologi Penelitian (Yogyakarta: Pustaka Pelajar, 1998), h. 126.
} h. 123. 
a. Metode Deskriptif

Metode deskriptif adalah suatu cara untuk mendeskripsikan dan menafsirkan apa yang ada, baik mengenai kondisi atau hubungan yang ada, pendapat yang sedang berkembang, proses yang sedang terjadi, akibat efek yang sedang terjadi atau kecenderungan yang sedang marak. ${ }^{49}$

b. Analisis konten

Analisin konten merupakan analisis terhadap maksud dan makna yang terkandung di dalam buku-buku yang menjadi referensi untuk mengetahui ide pokok. Kegunaan analisis konten adalah mengungkapkan isi buku yang mendeskripsikan pengetahuan atau eksplanasi yang ditunjukkan penulis saat menulis buku tersebut. ${ }^{50}$

c. Metode induktif

Adalah tahapan untuk mendapatkan kesimpulan yang dimulai dari sesuatu yang khusus kepada sesuatu yang bersifat umum. ${ }^{51}$

\section{Kepemimpinan Wanita dan Gender dalam Islam \\ 4.1 Posisi Wanita dalam Islam}

Diskursus tentang wanita adalah hal yang menarik, dikarenakan dalam rentang sejarah, "bertebaran" narasi-narasi tragis posisi wanita di berbagai bangsa di dunia. Fenomena yang terjadi di Yunani, Roma, Jerman, India, Cina dan Semenanjung Arabia adalah ketimpangan, ketidakadilan dan kesewenang-wenangan laki-laki terhadap perempuan dengan memperlakukan wanita sebagai hak kepemilikan yang ditempuh layaknya ketika membeli budak wanita. $^{52}$ Hal demikian merupakan fenomena dehumanisasi wanita yang terabadikan dalam realitas "panggung" sejarah dunia yang "memenjarakan" posisi wanita sebagai makhluk "setengah manusia".

Dalam kehidupan beragama, sering kali dijumpai penafsiran atas teks suci yang tendensius dan diskriminatif dan berakibat pada penempatan wanita pada posisi yang lemah dan terpinggirkan. ${ }^{53}$ Ajaran agama Yahudi memandang wanita sebagai makhluk terkutuk yang telah menggoda Adam a.s untuk memakan buah khuldi yang terlarang dan berujung pada "pengusiran" Adam a.s dari surga yang penuh kenikmatan. Bahkan, dalam Taurat digambarkan wanita sebagai makhluk yang lebih mengerikan daripada kematian. ${ }^{54}$ Dalam doktrin Hinduisme, wanita tidak diberikan kebebasan untuk menentukan jalan kehidupan yang terbaik menurut dirinya sendiri. Pada masa kanak-kanak wanita harus tunduk pada orang tua laki-lakinya, setelah menikah harus merelakan kedaulatannya di bawah kendali sang suami, bahkan ketika menjanda, wanita tidak dapat berbuat seenak hati harus bedasarkan "restu" saudara laki-lakinya. Dalam tradisi Kristen, wanita dinobatkan sebagai makhluk pembawa bencana dan sumber kejahatan, sehingga pantas untuk menempati posisi yang hina dina. ${ }^{55}$

Di tempat di mana agama Islam "dilahirkan", yaitu semenanjung Arabia, sebelum Islam "lahir" nasib wanita serupa dengan wanita dalam beberapa tradisi yang telah disebutkan di atas. Wanita Arab pada masa pra Islam sebagaimana informasi sejarah

${ }^{49}$ Saropah Faisal, Metode Penelitian Pendidikan (Surabaya: Usaha Nasional, 1994), h. 4.

${ }^{50}$ Hadi Nawawi, Metode Penelitian Sosial (Yogyakarta: Gajah Mada University Press, 1998), h. 95.

${ }^{51}$ M. Nizar, Metode Penelitian (Jakarta: Ghalia Indonesia, 1998), h. 63.

${ }^{52}$ Qasim Amin, Penindasan Wanita: Menggugat Islam Laki-laki Menggugat Perempuan Baru, terj. Syariful Alam, (Yogyakarta: IRCiSoD, 2003), h. 29.

${ }^{53}$ Maulana Muhammad Zaferuddin, Misi Seksual Islam, Melahirkan Kehormatan Diri dan Kesucian, (Jakarta: Sahara Publisher, 2004), h. 21. 1996), h. 13 .

${ }^{54}$ Abdullah A. Djawas, Dilemma wanita Karies Menuju Keluarga Sakinah, (Yogyakarta: Ababil,

${ }^{55}$ Mansour Fakih, Membincang Feminisme: Diskursus Gender dalam Perspektif Islam, (Surabaya: Risalah Gusti, 2000), h. 132-133. 
dianggap seperti barang komoditas perdagangan tidak lebih. Bahkan, masyarakat Arab pra Islam mengubur hidup anak mereka, jika yang lahir adalah seorang wanita karena dianggap tidak menguntungkan secara ekonomi dan membawa aib buruk untuk keluarga. ${ }^{56}$

Pasca Islam lahir, secara bertahap hak-hak wanita sebagai manusia "dipulihkan" kembali. Sebagai agama dengan misi rahmat li al- Âlamîn, Islam memproklamasikan keutuhun kemanusian wanita dan kesetaraan dengan posisi laki-laki. ${ }^{57}$ Risalah Islam yang dibawa oleh Nabi Muhammad SAW, perlahan merubah "pondasi" peradaban Arab Jahiliyyah yang merendahkan harkat, martabat dan posisi wanita. ${ }^{58}$ Langkah nyata yang ditempuh oleh Nabi Muhammad SAW telah berhasil merubah secara mendasar posisi wanita yang mengalami dehumanisasi pada era jahiliyyah abad ke-7 M. Nabi Muhammad SAW menganjurkan perayaan kelahiran bayi perempuan untuk membalik paradigma masyarakat Arab bahwa wanita adalah pembawa aib keluarga. Nabi Muhammad SAW juga merombak tatanan kewarisan perempuan, di mana pada masa pra Islam wanita menjadi objek waris menjadi subjek yang berhak mendapatkan harta waris berdasarkan ketentuan-ketentuan yang ditetapkan oleh syariat Islam. Selain itu, Nabi Muhammad SAW menetapkan kepemilikian mahar sebagai hak penuh wanita dalam perkawinan, di mana pada masa jahiliyyah merupakan hak monopoli wali. Lebih lanjut, Nabi Muhammad SAW mendekonstruksi praktik poligami yang telah "mendarah daging" dalam budaya bangsa Arab dengan mencontohkan perkawinan beliau dengan Khadijah. Fakta-fakta sejarah tersebut membuktikan bahwa Islam telah berhasil membawa perubahan mendasar terhadap posisi wanita dalam masyarakat. ${ }^{59}$ Dengan demikian, agama Islam telah mengangkat wanita dari "jurang" kelaliman dan kegelapan. Islam telah mengembalikan wanita menempati posisi yang mulia berdampingan dengan laki-laki dan kehidupan berdasarkan keadilan dari Sang Maha Pencipta. Laki-laki dan wanita keduanya adalah manusia, tidak ada perbedaan di antara mereka dari dimensi penciptaan dan kemanusiaanya. ${ }^{60}$

Namun demikian, kehidupan adalah kenyataan yang tidak pernah berhenti. ${ }^{61}$ Meskipun risalah al-Qur'an yang dibawa oleh Nabi Muhammad SAW telah berhasil merekonstruksi peradaban jahiliyyah yang menempatkan wanita dalam posisi yang eksploitatif dan diskriminatif, tidak berarti ketentuan-ketentuan yang berkaitan dengan wanita sudah mencapai "garis finish", karena posisi ideal wanita yang terwujud pada masa Nabi Muhammad SAW, perlahan mengalami degradasi setelah Nabi Muhammad SAW wafat. Wanita Islam kembali dihadapkan dengan pembatasan gerak-gerik pada ranah ruang publik. Umat Islam sepeninggal Nabi Muhammad SAW tidak sepenuhnya berhasil menghilangkan ekses patriarkisme yang sudah mengakar kuat dalam tradisi masyarakat Arab sebelum Islam lahir dan di daerah-daerah di mana Islam tersebar. ${ }^{62}$

Menurut Nasaruddin Umar, perjalanan sejarah ekspansi Islam yang mengharuskan adanya persentuhan dengan budaya patriarkis yang melekat pada tradisi masyarakat

${ }^{56}$ M. Faisol, Hermeneutika Gender Perempuan dalam Tafsir Bahr al-Muhith, (Malang: UIN-Maliki Press, 2011), h. 40-41.

57 Siti Musdah Mulia dan Anik Farida, Perempuan dan Politik, (Jakarta: Gramedia Pustaka Utama, 2005), h. 45.

${ }^{58}$ Ashgar Ali Engineer, Hak-hak Perempuan dalam Islam, terj. Farid Wajdi dan Cici Farkha Assegaf, (Bandung: LSPPA, 1994), h. 28.

59 Siti Musdah Mulia, Menuju Kemandirian Politik Perempuan, (Yogyakarta: Kibar Press, 2007), h. 21-22.

${ }^{60}$ Kurnia Ilahi, "Perempuan dalam Islam dan Kristen Katolik (Sebuah Telaah Teologi Kerukunan), Purari, Vol. 2. No. 1, Juni 2007, h. 12.

${ }^{61}$ Husein Muhammad, Islam Agama Ramah Perempuan: Pembelaan Kiai Pesantren, (Yogyakarta: LkiS, 2004), h. 191.

${ }^{62}$ Siti Musdah Mulia, Menuju Kemandirian Poltik Perempuan, h. 28. 
Asiria, Persia dan lain sebagainya membawa pengaruh pada hasil penafsiran teks kitab suci. Para sarjana tafsir dan fikih abad pertengahan terjebak pada "labirin" penafsiran yang masih kental "aroma" patriarkinya. Terlabih lagi, adanya keyakinan teologis, bahwa wanita diciptakan dari tulang rusuk Adam, wanita diciptakan hanya sebagai penyembuh dahaga hasrat Adam dan wanitalah yang menggoda Adam yang mengakibatkan diusirnya Adam dari surga dan mengakibatkan adanya "dosa warisan" (original sin). ${ }^{63}$

Agama Islam sangat menjunjung tinggi hak asasi manusia yang terimplementasi di dalam Piagam Madinah. ${ }^{64}$ Menurut pendapat sarjana fikih, hak asasi manusia merupakan sesuatu yang telah ditetapkan oleh syari'ah untuk semua manusia. ${ }^{65}$

Piagam Madinah adalah suatu piagam yang tertulis pertama kali dalam sejarah manusia yang berisi tentang dasar-dasar hak asasi manusia yang "berdiri" di atas asas-asas syari'at Islam. Pada bagian preambule piagam Madinah disebutkan bahwa manusia merupakan umat yang satu dan dilahirkan dari sumber yang sama. Jadi, tidak patut adanya sikap saling membeda-bedakan antara yang satu dengan yang lain. Hal yang harus dicatat adalah posisi manusia yang paling unggul di mata Allah SWT ditinjau dari aspek keimanan dan ketawakwaanya, bukan atas tolok ukur ras, suku, warna kulit, bangsa, serta jenis kelamin. ${ }^{66}$

Lebih lanjut, sebagai agama yang membawa misi kebebasan adalah suatu konsekuensi logis bahwa Islam melarang mengekang kebebasan kaum wanita, bahkan fakta sejarah membuktikan telah lahir dari "rahim" agama Islam sebuah revolusi pemikiran dan tindakan yang tegas dan lugas dalam rangka menghilangkan pekatnya sikap-sikap diskriminatif dan paternalistis. Islam telah memunculkan sosok-sosok wanita yang mempunyai paradigma luas tentang hakekat alam, manusia dan hidup. Ajaran Islam yang menjunjung tinggi semangat egaliter, keadilan dan kebebasan telah merubah wanita Islam menjadi tidak sekedar penurut pada tradisi yang merenggut kemualiaan posisinya sebagai manusia. ${ }^{67}$

Dalam QS. Al-Hujarat [49]: 13 Allah SWT berfirman:

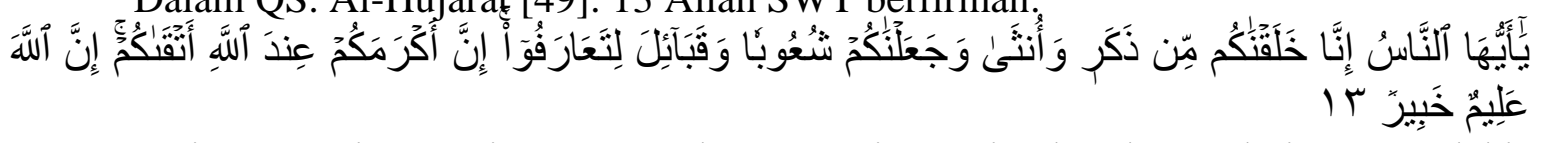

Artinya: "Hai manusia, sesungguhnya Kami menciptakan kamu dari seorang lakilaki dan seorang perempuan dan menjadikan kamu berbangsa-bangsa dan bersuku-suku supaya kamu saling kenal-mengenal. Sesungguhnya orang yang paling mulia diantara kamu disisi Allah ialah orang yang paling takwa diantara kamu. Sesungguhnya Allah Maha Mengetahui lagi Maha Mengenal".

Dari ayat tersebut di atas dapat dipahami bahwa laki-laki dan perempuan dapat menempati posisi yang mulia. Kemulian manusia tidaklah bedasarkan atas suku, keturunan, bangsa, jenis kelamin dan warna kulit.

Allah SWT berfirman dalam QS. Al-Nisa' [4]: 1 sebagai berikut:

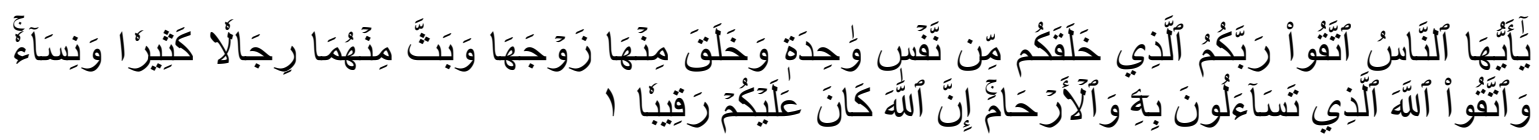

\footnotetext{
${ }^{63}$ Nasaruddin Umar, Teologi Jender: Mitos dan Teks Kitab Suci, (Jakarta: Pustaka Cicero, t.t), h. 154.

${ }^{64}$ Imran Siswa, "Hak Asasi Manusia dalam Piagam Madinah serta Prinsip-prinsip Konstitusi Madinah", Mahkamah, Vol. 2, No. 2 Oktober 2010, h. 169.

${ }^{65}$ Simposium Hak Asasi Manusia di antara Islam dan Undang-undang Dasar, h. 25.

${ }^{66}$ Imran Siswa, "Hak Asasi Manusia dalam Piagam Madinah serta Prinsip-prinsip Konstitusi Madinah", h. 169.
}

${ }^{67}$ Najmah Sa'idah Husnul Khatimah, Revisi Politik Perempuan (Bercermin pada Shahabiyah Ra), (Jakarta: Idea Pustaka, 2003), h. 193. 
Artinya: "Hai sekalian manusia, bertakwalah kepada Tuhan-mu yang telah menciptakan kamu dari seorang diri, dan dari padanya Allah menciptakan isterinya; dan dari pada keduanya Allah memperkembang biakkan laki-laki dan perempuan yang banyak. Dan bertakwalah kepada Allah yang dengan (mempergunakan) nama-Nya kamu saling meminta satu sama lain, dan (peliharalah) hubungan silaturrahim. Sesungguhnya Allah selalu menjaga dan mengawasi kamu".

Ayat tersebut di atas menunjukkan bahwa laki-laki dan wanita mempunyai kesamaan dalam segi asal-muasal, tempat tinggal dan tempat kembali.

Islam mengajarkan untuk menempatkan posisi wanita pada tempat yang mulia dan terhormat. Hal demikian berkesesuaian dengan prinsip keadilan yang terkandung di dalam hukum Islam ${ }^{68}$ karena pada dasarnya posisi laki-laki dan wanita adalah sama, jika ada hal yang "dianggap" berbeda adalah wujud dari perbedaan fungsi dan tugas utama yang diamanahkan Allah SWT kepada masing-masing jenis kelamin. Dengan demikian, tidak pantas laki-laki dan perempuan merasa mempunyai kelebihan dari yang lain.

Allah SWT menegaskan bahwa "sesungguhnya Allah SWT tidak menyia-nyiakan amal orang-orang yang beramal, baik laki-laki maupun wanita, keduanya yaitu laki-laki dan wanita mempunyai hak yang sama". ${ }^{69}$ Hal senada juga ditegaskan oleh Allah SWT dalam ayat lain, yaitu: "bagi laki-laki dianugerahkan hak (bagian) dari apa yang diusahakannya, dan bagi perempuan dianugerahkan dari apa yang diusahakannya". ${ }^{70}$ Ayatayat tersebut merupakan penjelasan al-Qur'an yang melenyapkan semua pandangan yang membedakan laki-laki dengan wanita, khususnya dalam bidang kemanusiaan.

Dari pemaparan tersebut di atas terlihat bahwa agama Islam telah memposisikan wanita pada tempat yang mulia, serta meluruskan konsep-konsep yang keliru yang berkaitan dengan kedudukan kaum wanita. Prinsisp keadilan merupakan pondasi yang harus ditegakkan dan diluruskan dalam sendi-sendi kehidupan masyarakat, karena menurut Islam jelas bahwa tidak ada kasta yang membedakan posisi antara laki-laki dan wanita, di mana salah satu dari kedua jenis kelamin lebih unggul dibandingkan jenis kelamin yang lain.

\subsection{Kesetaraan Gender dalam Islam}

Ketika diskursus gender diangkat, yang muncul dalam pikiran kita adalah gambaran diskriminatif terhadap wanita dan penghilangan hak-hak terhadap mereka. Gender yang telah diperjuangkan oleh beberapa kalangan, baik dari kalangan akademisi maupun dari kalangan yang menilai bahwa Islam adalah agama yang mendorong kehadiran isu gender tersebut di muka bumi ini. Tentunya, kalangan orientalis yang berbasis misionarisme ingin memojokkan posisi umat Islam dengan mengangkat isu ini dalam berbagai tulisan dan buku atau artikel-artikel yang menyudutkan dan memberikan pendapat secara sepihak tentang Islam dan gender. ${ }^{71}$

Agama Islam tidak meletakkan antara hak dan kewajiban yang ada pada anatomi manusia dalam posisi yang saling berlawanan, hak dan kewajiban itu selalu setara di mata Islam untuk kedua jenis kelamin yang berbeda tersebut. Islam menjunjung tinggi konsep

\footnotetext{
${ }^{68}$ Nilai dasar keadilan manusia secara fitrah merupakan keadilan yang terpancar dari Tuhan, karena manusia adalah theopany kebebasan Tuhan. Kebebasan manusia secara mutlak berarti pendustaan terhadap kenyataan penyerahan pada kehendak Nya. Lihat Abdul Ghofur Anshori, Filsafat Hukum Kewarisan Islam, (Yogyakarta: UII Press, 2005), h. 191.

${ }^{69}$ QS. Ali Imran [3]: 195.

${ }^{70}$ QS. Al-Nisa’ [4]: 32.

71 Mansour Fakih, dkk, Membincang Feminisme Diskursus Gender Perspektif Islam, (Surabaya: Risalah Gusti, 2006), h. 11.
} 
keadilan untuk siapapun tanpa melihat jenis kelamin mereka. Islam merupakan agama yang terdepan dalam usaha membebaskan belenggu tirani perbudakan, kesetaraan hak dan tidak pernah memberikan prestise salah satu jenis kelamin saja. Islam lahir sebagai agama yang menebar kasih dan sayang bagi siapa saja. ${ }^{72}$

Dalam buku Se and society, gender didefinisikan sebagai behavior differences antara laki-laki dan wanita yang secara sosial berbeda, yaitu perbedaan yang bukan pada kodrat atau ciptaan Tuhan, namun perbedaan antara laki-laki dan wanita dikarenakan adanya proses budaya dan sosial yang dinamis dan dalam waktu yang panjang. ${ }^{73}$

Dalam buku Women"s Studies Encyclopedia, gender diartikan sebagai suatu konsep kultural yang berkembang di masyarakat dan mempunyai "visi" untuk melahirkan perbedaan peran, perilaku, mentalitas dan karakter emosional antara laki-laki dan wanita. ${ }^{74}$

Term gender berasal dari kosakata Bahasa Inggris yang bermakna jenis kelamin. ${ }^{75}$ Dalam buku Sex and Gender karya Hilary M. Lips, gender diartikan sebagai harapanharapan budaya terhadap laki-laki dan wanita. Misalnya: wanita dikenal sebagai sosok yang lemah lembut, cantik, emosional dan keibuan. Sementara itu, laki-laki dianggap sebagai sosok yang kuat, rasional, jantan dan perkasa. Karakteristik dari sifat itu adalah sifat yang dapat dipertukarkan, misalnya: ada laki-laki yang mempunyai sikap lemah lembut, ada perempuan yang kuat, rasional dan perkasa. Dengan demikian, perubahan ciri dari sifat-sifat tersebut dapat terjadi dari waktu ke waktu dan dari tempat ke tempat yang lain. $^{76}$

Allah SWT menciptakan bentuk fisik dan tabiat wanita berbeda dengan laki-laki. Kaum laki-laki diberikan kelebihan oleh Allah SWT baik fisik maupun mental atas kaum wanita sehingga pantas kaum pria sebagai pemimpin atas kaum wanita terdapat di dalam Al-Quran pada surat Al-Nisa' [4]: 35. Sehingga, secara asal nafkah bagi keluarga merupakan tanggug jawab kaum laki-laki. Al-Syaikh Ibn Baaz berkata: "Islam menetapkan masing-masing dari suami dan istri mempunyai kewajiban yang khusus agar keduanya menjalankan perannya, sehingga sempurnalah bangunan masyarakat di dalam dan di luar rumah. Suami berkewajiban mencari nafkah dan penghasilan sedangkan istri berkewajiban mendidik anak-anaknya, memberikan kasih sayang, menyusui dan mengasuh mereka serta tugas-tugas lain yang sesuai baginya, mengajar anak-anak perempuan, mengurusi sekolah mereka, dan mengobati mereka serta pekerjaan lain yang khusus bagi kaum wanita. Jika wanita sampai meninggalkan kewajiban dalam rumahnya berarti ia menyianyiakan rumah berikut penghuninya. Hal tersebut berdampak terpecahnya keluarga baik secara hakiki maupun maknawi. ${ }^{77}$

Dalam perspektif Islam, semua yang diciptakan Allah SWT berdasarkan kudratnya masing-masing. Para pemikir Islam mengartikan qadar di dalam al-Qur'an sebagai ukuran-ukuran, sifat-sifat yang ditetapkan Allah SWT bagi segala sesuatu, dan itu dinamakan kudrat. Dengan demikian, laki-laki dan wanita sebagai individu dan jenis kelamin memiliki kudratnya masing-masing. Mahmud Syaltut mengatakan bahwa tabiat kemanusiaan antara laki-laki dan wanita berbeda, namun dapat dipastikan bahwa Allah

${ }^{72}$ Mansour Fakih, dkk, Membincang Feminisme Diskursus Gender Perspektif Islam, h.11.

${ }^{73}$ Dzuhayatin dan Siti Ruhaini, Rekonstruksi Metodologis Wacana Kesetaraan Gender dalam Islam, (Yogyakarta: PSW IAIN Sunan Kalijga, 2017), h. 18.

${ }^{74}$ Leonard Grob, Riffat Hasan dan Hain Gordon, “Jihad fi Sabilillah, "Women's Faith Journey From Struggel to Struggle, dalam buku Women's and Men's Liberation, (USA: Greenwood Press, 1993), h. 11-13.

${ }^{75}$ Jhon Echol dan Hasan Sadily, Kamus Inggris-Indonesia, (Jakarta: PT Gramedia, 2001), h. 176.

76 Secara historis wanita Pakistan hanya menjadi ibu dan pembantu rumah tangga, mereka tidak mendapatkan pendidikan formal secara layak, sebagai bias dari kolonial Barat. Nasra M. Shah (ed), Pakistani Women A Socio-Economic and Demographic Profile, (Islamabad: Pakistan Institute of Development Economics, t. th), h. 22.

${ }^{77}$ Mansour Fakih, dkk, Membincang Feminisme Diskursus Gender Perspektif Islam, h.12. 
SWT telah menganugerahkan potensi dan kemampuan kepada perempuan sebagaimana telah menganugerahkannya kepada laki-laki. Ayat al-Qur'an yang populer dijadikan rujukan dalam pembicaraan tentang asal kejadian perempuan adalah firman Allah dalam QS. Al-Nisa' [4]: $1 .^{78}$

Kata nafs dalam QS. Al-Nisa' [4]: 1 menurut ulama tafsir adalah Adam dan pasangannya adalah Siti Hawa. ${ }^{79}$ Pandangan ini kemudian telah melahirkan pandangan negatif kepada wanita berupa pernyataan bahwa wanita adalah bagian laki-laki. ${ }^{80}$ Tanpa laki-laki wanita tidak ada, bahkan tidak sedikit di antara mereka berpendapat bahwa Hawa diciptakan dari tulang rusuk Adam. ${ }^{81}$

Kalaupun pandangan di atas diterima yang mana asal kejadian Hawa dari rusuk Adam, maka harus diakui bahwa ini hanya terbatas pada Hawa saja, karena anak cucu mereka baik laki-laki maupun perempuan berasal dari perpaduan sperma dan ovum. Allah SWT menegaskan hal ini dalam QS. Ali Imran [3]: 195.

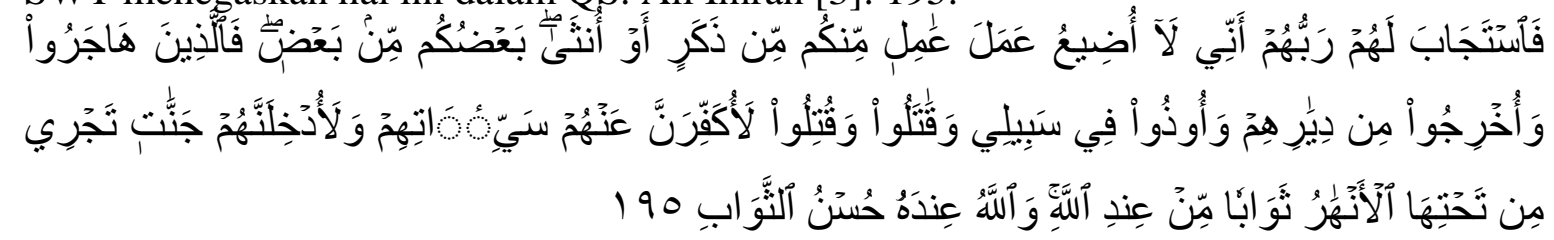

Artinya: "Maka Tuhan mereka memperkenankan permohonannya (dengan berfirman): "Sesungguhnya Aku tidak menyia-nyiakan amal orang-orang yang beramal di antara kamu, baik laki-laki atau perempuan, (karena) sebagian kamu adalah turunan dari sebagian yang lain. Maka orang-orang yang berhijrah, yang diusir dari kampung halamannya, yang disakiti pada jalan-Ku, yang berperang dan yang dibunuh, pastilah akan Ku-hapuskan kesalahan-kesalahan mereka dan pastilah Aku masukkan mereka ke dalam surga yang mengalir sungai-sungai di bawahnya, sebagai pahala di sisi Allah. Dan Allah pada sisi-Nya pahala yang baik".

Adanya perbedaan antara laki-laki dan wanita tidak dapat disangkal karena memiliki kodrat masing-masing. ${ }^{82}$ Perbedaan tersebut paling tidak dari segi biologis. ${ }^{83} \mathrm{Al}-$ Qur'an mengingatkan: "dan janganlah kamu iri hati terhadap apa yang dikaruniakan Allah kepada sebahagian kamu lebih banyak dari sebahagian yang lain. (karena) bagi orang lakilaki ada bahagian dari pada apa yang mereka usahakan, dan bagi para wanita (pun) ada bahagian dari apa yang mereka usahakan, dan mohonlah kepada Allah sebagian dari karunia-Nya. Sesungguhnya Allah Maha mengetahui segala sesuatu". ${ }^{84}$

${ }^{78}$ Abudin Nata, Metodologi Studi Islam, (Jakarta: PT Grafindo Persada, 2006), h. 23.

${ }^{79}$ Wahbbah al-Zuhailî, Al-Tafsîr al-Wajîz 'alâ Hâmisy al-Qur'ân al- 'Až̂im, (Suriah: Dâr al-Fikr, t.t), h.

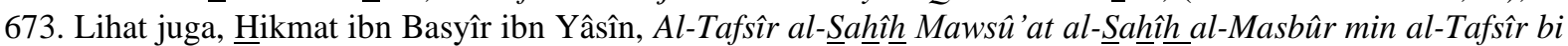
al-Ma'tsûr, "(Madinah: Dâr al-Mâtsir, 1999), jilid 2, h. 3. Lihat juga, 'Abû Muhammad 'Abd al-Haqq ibn Ghâlib ibn 'Atịyyah al-'Andalusî, Al-Munarral al-Wajîz fî̀ Tafsîr al-Kitâb al-'Azîz, (Beirut: Dâr al-Kutub al'Ilmiyyah, 2001), juz 2, h. 3-4.

${ }^{80}$ Djohan Effendi, Pembaruan Tanpa Membongkar Tradisi: Wacana Keagamaan di Kalangan Generasi Muda NU Masa Kepemimpinan Gus Dur, (Jakarta: PT Kompas Media Nusantra, 2010), h. 231.

${ }^{81}$ Nurjannah Ismail, Perempuan dalam Pasungan: Bias Laki-laki dalam Penafsiran, (Yogyakarta: LkiS Yogyakarta, 2003), h. 265. Lihat juga, Zaitunah Subhan, Al-Qur'an dan Perempuan: Menuju Kesetaraan Gender dalam Penafsiran, (Jakarta: Prenadamedia Group, 2015), h. 296.

82 Murtadha Muthahhari, Filsafat Perempuan dalam Islam: Hak Perempuan dan Relevansi Etika Sosial, (T.tp: Abbaz Production, t.t), h. 6.

83 Ali Masykur Musa berpendapat bahwa gender adalah alat "kelamin sosial" yang dapat berubah, sementara seks adalah alat kelamin biologis yang bersifat permanen. Ali Masykur Musa, Membumikan Islam Nusantara: Respons Islam Terhadap Isu-isu Aktual, (Jakarta: PT Serambi Ilmu Semesta, 2014), h. 59.

${ }^{84}$ QS. Al-Nisa' [4]: 32. 
Ayat tersebut di atas mengisyaratkan perbedaan, dan bahwa masing-masing memiliki keistimewaan. Walaupun demikian, ayat ini tidak menjelaskan apa keistimewaan dan perbedaan itu. Namun dapat dipastikan bahwa perbedaan yang ada tentu mengakibatkan fungsi utama yang harus mereka emban masing-masing. ${ }^{85} \mathrm{Di}$ sisi lain, dapat pula dipastikan tiada perbedaan dalam tingkat kecerdasan dan kemampuan berfikir secara inherent (hakiki) antara kedua jenis kelamin itu. ${ }^{86}$ Al-Qur'an memuji 'ulu al-Albâb, yaitu orang-orang yang berzikir dan memikirkan tentang kejadian langit dan bumi. Zikir dan fikir dapat mengantar manusia mengetahui rahasia-rahasia alam raya. ${ }^{87}$ 'Ulu al-albâb tidak terbatas pada kaum laki-laki saja, namun juga kaum wanita, karena setelah al-Qur'an menguraikan sifat-sifat ulul albab ditegaskannya bahwa "Maka Tuhan mereka mengabulkan permintaan mereka dengan berfirman; "Sesungguhnya Aku tidak akan menyia-nyiakan amal orang yang beramal di antara kamu, baik lelaki maupun perempuan". ${ }^{88}$ Ini berarti bahwa kaum wanita sejajar dengan laki-laki dalam potensi intelektualnya, mereka juga dapat berpikir, mempelajari kemudian mengamalkan apa yang mereka pahami dari zikir kepada Allah SWT serta apa yang mereka pikirkan dari alam raya ini.

Kaum laki-laki dan wanita sama di hadapan Allah. Memang ada ayat yang menegaskan bahwa "para laki-laki (suami) adalah pemimpin para perempuan (istri)", 89 namun kepemimpinan ini tidak boleh menjadikannya berlaku sewenang-wenang, karena di sisi lain al-Qur'an memerintahkan untuk saling tolong-menolong antara laki-laki dan wanita, terlebih al-Qur'an memerintahkan pula agar suami dan istri hendaknya mendiskusikan dan memusyawarahkan persoalan mereka bersama. ${ }^{90}$

Islam adalah sistem kehidupan yang mengantarkan manusia untuk memahami realitas kehidupan. ${ }^{91}$ Islam juga merupakan tatanan global yang diturunkan Allah SWT sebagai rahmat li al- 'Alamîn. ${ }^{92}$ Sehingga-sebuah konsekuensi logis- jika penciptaan Allah SWT atas makhluk-Nya - laki-laki dan wanita-memiliki misi sebagai khalifatullâh fî al$a r d h$, yang memiliki kewajiban untuk menyelamatkan dan memakmurkan alam, sampai pada suatu kesadaran akan tujuan menyelamatkan peradaban kemanusiaan. ${ }^{93}$ Dengan demikian, wanita dalam Islam memiliki peran yang konprehensif dan kesetaraan harkat dan martabat sebagai hamba Allah SWT serta mengemban amanah yang sama dengan laki-laki.

Berangkat dari posisi di atas, wanita muslim mempunyai peran yang sangat strategis dalam mendidik umat, memperbaiki masyarakat dan membangun peradaban, sebagaimana yang telah dilakukan oleh sahabat wanita dalam mengantarkan masyarakat

${ }^{85}$ Khaeron Sirin, Perkawinan Mazhab Indonesia : Pergulatan Antara Negara, Agama dan Perempuan, (Yogyakarta: Deepublish, 2018), h. 110. Lihat juga, Ali Ahmad al-Jarwi, Indahnya Syariat Islam, terj. Faisal Saleh, dkk, (Jakarta: Gema Insani, 2006), h. 167.

${ }^{86}$ Nurjannah Ismail, Perempuan dalam Pasungan: Bias Laki-laki dalam Penafsiran, h. 66.

${ }^{87}$ Yusep Rafiqi, Belajar Hidup dari Allah: 7 Etos Suci Al-Fatihah untuk Kebahagiaan Dunia-Akhirat, (Jakarta: PT Elex Media Komputindo, 2015), h. 112. Lihat juga, Sayyid Qutb, Tafsir fi Zhilalil Qur'an: Di Bawah Nauangan al-Qur'an, terj. As'ad Yasin, dkk, (Jakarta: Gema Insani Press, 2003), jilid 7, h. 47-48.

${ }^{88}$ QS. Ali Imran [3]: 195.

${ }^{89}$ QS. Al-Nisa' [4]: 34.

${ }^{90}$ Abudin Nata, Metodologi Studi Islam, h. 142.

${ }^{91}$ Budhy Munawar-Rachman, Argumen Islam untuk Sekularisme: Islam Progresif dan Perkembangan Diskursusnya, (Jakarta: PT Gramedia Widiasarana, 2010), h. 84.

${ }^{92}$ Darsono Yusin Sali, Meneguhkan Keislaman \& Keindonesiaan, (Yogyakarta: Deepublish, 2018), h. $227-228$

93 Ika Rochdjatun Sastrahidayat, Cahaya Illahi Yang Hilang, (Malang: Universitas Brawijaya Press, 2013), h. 184. 
yang hidup di zamannya pada satu keunggulan peradaban. ${ }^{94}$ Mereka berperan dalam masyarakatnya dengan azzam yang tinggi untuk mengoptimalkan seluruh potensi yang ada pada diri mereka, sehingga kita tidak menemukan satu sisipun dari seluruh aspek kehidupan mereka terabaikan. Mereka berperan dalam setiap waktu, ruang dan tataran kehidupan mereka.

Kesadaran para shahabiyat untuk berperan aktif dalam dinamika kehidupan masyarakat terbangun dari pemahaman mereka tentang syumuliyyat al-Islâm, sebagai buah dari proses pendidikan bersama Rasulullah SAW. ${ }^{95}$ Islam yang mereka pahami dalam dimensinya yang utuh sebagai way of life, membangkitkan kesadaran akan amanah untuk menegakkan risalah itu sebagai sokoguru perdaban dunia. ${ }^{96}$ Dalam perjalanannya, terjadi pergeseran pemahaman Islam para wanita muslim yang berakibat pada apresiasi mereka terhadap terhadap nilai-nilai Islam - khususnya terkait masalah kedudukan dan peran wanita-sedemikian hingga mereka meragukan keabsahan normatif nilai-nilai tersebut. ${ }^{97}$ Hal ini muncul dikarenakan "jauhnya” umat ini secara umum dari al-Qur'an dan Sunnah. Di samping itu, di sisi lain pergerakan feminis dengan konsep gendernya menawarkan berbagai "prospek"-lewat manuvernya secara teoritis maupun praktis - tanpa umat ini memiliki kemampuan yang memadai untuk mengantisipasi sehingga sepintas mereka tampil menjadi pemecah masalah berbagai permasalahan wanita yang berkembang. Pada gilirannya konsep gender-kemudian cenderung diterima mentah-mentah oleh kalangan wanita muslim tanpa ada penelaahan kritis tentang hakekat dan implikasinya. ${ }^{98}$

Dalam tradisi Yahudi dan Kristen terdapat tiga asumsi teologis, di mana suprastruktur superioritas laki-laki atas wanita (yang mengimplikasikan ketidaksetaraan laki-laki dan perempuan) ditegakkan. Tiga asumsi tersebut adalah:

1) Isu penciptaan manusia. Bahwa ciptaan Tuhan yang utama laki-laki bukan perempuan. Karena perempuan diyakini telah diciptakan dari tulang rusuk laki-laki, karenanya secara ontologis bersifat derivatif dan sekunder. Menurut Riffat penciptaan Hawa dari tulang rusuk merupakan keyakinan yang berakar kokoh dari Injil dan bertentangan dengan al-Quran. Kalaupun ada 6 (enam) hadist nabi yang mendukung penciptaan perempuan dari tulang rusuk laki-laki, menurut analisisnya, adalah dho'if karena memiliki sejumlah perawi yang tidak bisa dipercaya.

2) Perempuan adalah penyebab kejatuhan diusirnya manusia dari surga, dan bukannya laki-laki. Riffat menolak interpretasi yang selalu mendiskreditkan wanita. Menurutnya tidak ada konsep kejatuhan dalam al-Qur'an, karenanya tidak ada dosa asal.

3) Perempuan diciptakan tidak saja dari laki-laki, tapi juga untuk laki-laki, yang membuat eksistensinya semata-mata bersifat instrumental dan tidak memiliki makna yang mendasar. Menurut Riffat, pendapat ini bertentangan dengan al-Qur'an yang menjelaskan bahwa manusia diciptakan hanya untuk mengabdi kepada Allah dan dengan sebaikbaik bentuk. Laki-laki dan wanita setara di hadapan Allah SWT. ${ }^{99}$

94 Samsul Nizar. "PENDIDIKAN PEREMPUAN: Kajian Sejarah yang Terabaikan." Lentera Pendidikan: Jurnal Ilmu Tarbiyah dan Keguruan 11.1 (2017): 1-18.

${ }^{95}$ Khaled M, Abou El Fadl, Atas Nama Tuhan: Dari Fikih Otoriter ke Fikih Otoritatif, terj. R. Cecep Lukman Yasin, (Jakarta: PT Serambi Ilmu Semesta, 2003), h. 337-338.

${ }^{96}$ Fajar Riza Ul Haq, Membela Islam, Membela Kemanusiaan, (Bandung: PT Mizan Pustaka, 2017), h. 200-201.

97 Saifuddin dan Wardani, Tafsir Nusantara: Analisis Isu-isu Gender dalam Al-Mishbah Karya M. Quraish Shihab dan Tarjuman al-Mustafid Karya 'Abd al-Ra'uf Singkel, (Yogyakarta: LkiS, 2017), h. viii.

${ }^{98}$ Kasmawati, “Gender dalam Perspektif Islam”, Sipakalebbi’, Vol. 1, No. 1Mei 2013, h. 9.

${ }^{99}$ Leonard Grob, Riffat Hasan dan Hain Gordon, "Jihad fi Sabilillah, "Women's Faith Journey From Struggel to Struggle, dalam buku Women's and Men's Liberation, h. 20. 
Ketiga asumsi tersebut, secara filosofis maupun teologis adalah hal yang paling mendasar dalam konteks kesetaraan laki-laki-wanita. Sebab, jika laki-laki dan perempuan telah diciptakan setara oleh Allah SWT sebagai penentu nilai tertinggi, maka di kemudian hari tidak bisa berubah menjadi tidak setara. Di sisi lain, jika laki-laki dan wabita diciptakan tidak setara oleh Allah SWT, maka secara esensial di kemudian hari tidak bisa menjadi setara. Anggapan Hawa diciptakan dari tulang rusuk Adam yang berakar kuat di kalangan Muslim berasal dari bangunan ide dan sikap yang sama di kalangan Yahudi dan Kristen. Dalam Kitab Kejadian 2: 8-24 dinyatakan bahwa perempuan tercipta dari laki-laki yang secara umum konsep ini dipahami, Adam adalah ciptaan yang utama, Hawa adalah ciptaan sekunder yang hanya bersifat sebagai subordinat Adam, pendek kata, penciptaan Hawa hanya ditakdirkan sebagai pembantu Adam. ${ }^{100}$

Dalam agama Islam, hubungan manusia dengan manusia lain maupun hubungan manusia dengan makhluk lain adalah hubungan antar obyek. Jika ada kelebihan manusia dari makhluk lainnya maka ini adalah kelebihan yang potensial saja sifatnya untuk dipersiapkan bagi tugas dan fungsi kemanusiaan sebagai hamba (sama seperti jin) ${ }^{101}$ dan khalîfatullâh. ${ }^{102}$

Kelebihan yang disyaratkan sebagai kelebihan pengetahuan (konseptual) menempatkan manusia untuk memiliki kemampuan yang lebih tinggi dari obyek makhluk lain dihadapan Allah. Akan tetapi kelebihan potensial ini bisa saja menjadi tidak berarti ketika tidak digunakan sesuai fungsinya atau bahkan menempatkan manusia lebih rendah dari makhluk yang lain. ${ }^{103}$ Secara normatif, pemihakan wahyu atas kesetaraan kemanusiaan laki- laki dan wanita dinyatakan di dalam QS. Al-Taubah [9] :71. Kelebihan tertentu laki-laki atas perempuan dieksplisitkan QS. Al-Nisa' [4]: 34 dalam kerangka yang konteksual, sehingga tidak kemudian menjadikan yang satu adalah subordinat yang lain. Dalam kerangka yang normatif inilah nilai ideal universal wahyu relevan dalam setiap ruang dan waktu. Sedangkan dalam kerangka konstektual, wahyu mesti dipahami lengkap dengan latar belakang konteksnya (asbâb al-Nuzûl) yang dalam pandangan Ali Ashgar Engineer terformulasikan dalam bahasa hukum (syari'at). Syari'at adalah suatu wujud formal wahyu dalam kehidupan manusia yang menjadi ruh kehidupan masyarakat. ${ }^{104}$ Antara wahyu (normatif) dengan masyarakat (konteks) selalu ada hubungan dinamis sebagaimana al-Qur'an itu sendiri turun dengan tidak mengabaikan realitas masyarakat, tetapi dengan cara berangsur dan bertahap.

Dengan proses yang demikian idealitas Islam adalah idealitas yang realistis bukan elitis atau utopis karena jauhnya dari realitas konteks.

Dari penelusuran penulis paling tidak ada dua faktor yang menghambat perjuangan gender, yaitu:

a. Faktor internal yang merupakan faktor dari dalam diri wanita itu sendiri, misalnya perempuan selalu mempersepsikan status dirinya berada di bawah status laki-laki, sehingga tidak mempunyai keberanian dan kepercayaan diri untuk maju

b. Faktor ekternal yaitu faktor yang berada diluar diri perempuan itu sendiri, dan hal yang paling dominan adalah terdapatnya nilai-nilai budaya patriarki yang mendominasi segala kehidupan di dalam keluarga masyarakat, sehingga menomor duakan peran perempuan.

${ }^{100}$ Leonard Grob, Riffat Hasan dan Hain Gordon, “Jihad fi Sabilillah, "Women's Faith Journey From Struggel to Struggle, dalam buku Women's and Men's Liberation, h. 45.

${ }^{101}$ QS. Al-Dzhariyat [51]: 56.

102 QS. Al-Baqarah [2]: 30.

${ }^{103}$ Ashghar Ali Engineer, The Rigts of Women in Islam, (London: C. Hurst and Co., 1992), h. 122.

${ }^{104}$ Ashghar Ali Engineer, The Rigts of Women in Islam, h. 122. 
Selain itu, juga interprestasi agama yang bias gender, kebijakan umum, peraturan perundang-undangan dan sistem serta aparatur hukum yang dikriminatif serta bias gender, baik di pusat maupun daerah. Di samping itu juga masih kuatnya budaya sebagian besar masyarakat yang menganggap perempuan kurang berkiprah di ruang publik, ditambah dengan adanya ajaran agama yang dipahami secara keliru, membuat perjuangan perempuan untuk mencapai keadilan dan kesetaraan gender semakin sulit tercapai.

\section{KESIMPULAN}

Seorang pemimpin adalah figur yang mengembang tugas fungsional untuk mengawal proses dalam rangka mempengaruhi pikiran, perilaku dan perasaan orang lain, baik kelompok maupun perorangan untuk menuju tujuan bersama. Dalam Islam, dikenal beberapa prinsip kepemimpinan, yaitu: tanggung jawab, tauhid, musyawarah, dan adil. Kepemimpinan perempuan seringkali menjadi isu kontroversial dalam masyarakat Islam, ada yang mendukung dan ada juga yang menolak. Semntara itu, dalam perspektif kesetaran gender, terdapat keyakinan bahwa agama Islam tidak meletakkan antara hak dan kewajiban yang ada pada anatomi manusia dalam posisi yang saling berlawanan, hak dan kewajiban itu selalu setara di mata Islam untuk kedua jenis kelamin yang berbeda tersebut. Islam menjunjung tinggi konsep keadilan untuk siapapun tanpa melihat jenis kelamin mereka. Islam merupakan agama yang terdepan dalam usaha membebaskan belenggu tirani perbudakan, kesetaraan hak dan tidak pernah memberikan prestise salah satu jenis kelamin saja. Islam lahir sebagai agama yang menebar kasih dan sayang bagi siapa saja.

\section{DAFTAR PUSTAKA}

'Abd al-Ghani al-Diqr, Al-Imam al-Syafi'i: Faqih al-Sunnah al-Akbar, Damaskus: Dar alQalam, 1996.

'Abd al-Halim al-Jundi, Al-Imam al-Syafi'i Nashir al-Sunnah wa Wadhi' al-Ushul, Kairo: Dar al-Ma'arif, t.t.

'Abd Allah ibn 'Abd al-Muhsin al-Turki, Ushul Madzahib al-Imam Ahmad, Riyadh: Maktabah al-Riyadh al-Haditsah, 1990.

'Abû Ja'far Muhammad ibn Jarîr al-Tabarî, Târîkh al-Rusul wa al-Mulûk, Mesri: Dâr alMa'ârif, t,t.

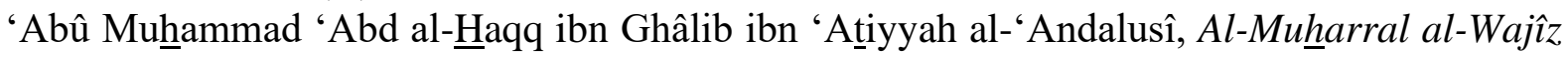
fì Tafsîr al-Kitâb al-'Azîz, Beirut: Dâr al-Kutub al-'Ilmiyyah, 2001.

'Âsyûr, Muhammad Thâhir ibn, Tafsîr al-Tahrîr wa al-Tanwîr, Tûnis: Al-Dâr al-Tûnisiyyah, 1984.

A. Fatih Syuhud, Wanita Shalihah Wanita Modern, Malang: Pustaka Alkhoirot, 2009.

Abbas Mahmud al-Aqqad, Filsafat al-Qur'an: Filsafat, Spiritual dan Sosial dalam Isyarat al-Qur'an, Jakarta: Pustaka Firdaus, 1986.

Abd al-Rahman al-Syarqawi, Riwayat 9 Imam Fiqih, Bandung: Pustaka Hidayah, 2000.

Abdul Hadi, "Posisi Wanita dalam Sistem Politik Islam Perspektif Fenomelogi." An Nisa'a 12.1 (2017).

Abdul Halim Abu Syuqqah, Kebebasan Wanita, terj. Chirul Halim, Jakarta: Gema Insani Press, 1997.

Al-'Andalusî, 'Abû Hayyan, Tafsîr al-Bahr al-Muhhit, Beirut: Dâr al-Kutub al-'Ilmiyyah, 1993.

Al-Baghawî, 'Abû Muhammad al-Husain ibn Mas'ûd, Tafsîr al-Baghawî̀: Ma'âlim al-Tanzîl, Riyadh: Dar Thayyibah li al-Nasyar wa al-Tawzi’, 1409 H. 
Al-Baghdadi, 'Abu al-Hasan Ali ibn Muhammad ibn Habib al-Bashri, Al-Ahkam alSulthaniyyah wa al-Wilayat al-Diniyyat, Beirut: Dar al-Kutub al-Ilmiyyah, 2006.

Al-Banjari, Rachmat Ramadhana, Prophetic Leadership, Yogyakarta: DIVA Press, 2008.

Al-Bâqî, Muhammad Fu'ad 'Abd, Al-Mu'jam al Mufahras li al-Fazh al-Qur'ân al-Karîm, Beirut: Dar al-Fikr, $1407 \mathrm{H}$.

Al-Dimasyqî,, 'Imâd al-Dîn 'Abî al-Fidâ' 'Ismâ'̂̂l, Tafsîr al-Qur'ân al-'Azhîm, Mesir, Mu'assasah Qurthubah, t.t.

Ali Ahmad al-Jarwi, Indahnya Syariat Islam, terj. Faisal Saleh, dkk, Jakarta: Gema Insani, 2006.

Ali Masykur Musa, Membumikan Islam Nusantara: Respons Islam Terhadap Isu-isu Aktual, Jakarta: PT Serambi Ilmu Semesta, 2014.

Al-Mahallî, Jalâl al-Dîn Muhammadi ibn 'Aḥmad dan Jalâl al-Dîn 'Abd al-Rahmân ibn 'Abî Bakar al-Suyûthî, Tafsîr al-Qur'ân al- 'Azhîm li al-Imâm al-Jalailain, Surabaya: Dâr al-'Abidîn, tt

Al-Qâsimî, Muhammad Jamâl al-Dîn, Tafsîr al-Qâsimî al-Musammâ Mahasin al-Ta'wîl, Bairut: Dâr al-Kutub al-'Ilmiyyah, 2003.

Al-Suyûtîn, Jalâl al-Dîn, Al-Dûr al-Mantsûr fî al-Tafsîr bi al-Ma'tsûr, Kairo: Markaz Hajr li al-Buhûts wa al-Dirâsât al-'Arabiyyah wa al-'Islâmiyyah, 2003.

Al-Thabarî, 'Abû Ja'far Muhammad ibn Jarîr, Tafsîr al-Thabarî, Kairo: Maktabah Ibn Taimiyyah, t.t.

Al-Zamakhsyarî , Abû al-Qâsim Mahmûd ibn 'Umar, Al-Kasysyâf 'an Gawâmizh al-Tanzîl wa 'Uyûn al-'Aqâwîl fî̀ Wujûh al-Ta'wîl, Riyad: Maktabah al-'Abîkân, 1998.

Amin, Qasim, Penindasan Wanita: Menggugat Islam Laki-laki Menggugat Perempuan Baru, terj. Syariful Alam, Yogyakarta: IRCiSoD, 2003.

Anshori, Abdul Ghofur, Filsafat Hukum Kewarisan Islam, Yogyakarta: UII Press, 2005.

Arbcrry, A. J., Revelation and Reason in Islam, London: George Allen \&Unwin Ltd., 1975

Ashadi Zain, Jejak Bisnis Khadijah, terj. Gita Romadhona, Jakarta: Hikmah (PT Mizan Publika), 2008.

Asy’arie, Musa, Manusia Pembentuk Kebudayaan dalam Al Qur'an, Yogyakarta: LESFI, 1992.

Bonnie G. Smith, The Oxford Encyclopedia of Women in World History, New York: Oxford University Press, 2008.

Budhy Munawar-Rachman, Argumen Islam untuk Sekularisme: Islam Progresif dan Perkembangan Diskursusnya, Jakarta: PT Gramedia Widiasarana, 2010.

Darsono Yusin Sali, Meneguhkan Keislaman \& Keindonesiaan, Yogyakarta: Deepublish, 2018.

Dzuhayatin dan Siti Ruhaini, Rekonstruksi Metodologis Wacana Kesetaraan Gender dalam Islam, Yogyakarta: PSW IAIN Sunan Kalijga, 2017.

Echol, Jhon dan Hasan Sadily, Kamus Inggris-Indonesia, Jakarta: PT Gramedia, 2001.

Engineer, Ashgar Ali, Hak-hak Perempuan dalam Islam, terj. Farid Wajdi dan Cici Farkha Assegaf, Bandung: LSPPA, 1994.

Ergun Mehmet Caner, Voice Behind the Veil: The World of Islam Through rhe Eyes of Women, USA: Kregel Publications, 2003.

Fadwa El Guindi, Jilbab antara Kesalehan, Kesopanan dan Perlawan terj. Mujiburohman, Jakarta: PT Serambi Ilmu Semesta, 2005.

Faisol, M., Hermeneutika Gender Perempuan dalam Tafsir Bahr al-Muhith, Malang: UINMaliki Press, 2011.

Fajar Riza Ul Haq, Membela Islam, Membela Kemanusiaan, Bandung: PT Mizan Pustaka, 2017. 
Fakih, Mansour, Membincang Feminisme: Diskursus Gender dalam Perspektif Islam, Surabaya: Risalah Gusti, 2000.

Georgina L. Jardim, Recovering the Female Voice in Islamic Scripture: Women and Silence, New York: Routledge, 2016.

Heinz Halm, The Fatimids and Their Traditions of Learning, New York: I.B. Tauris \& Co. Ltd, 1997.

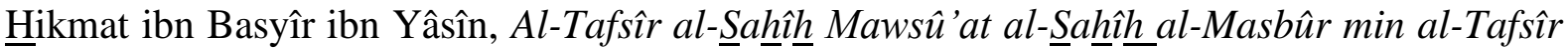
bi al-Ma'tsûr, Madinah: Dâr al-Mâtsir, 1999.

Husein Muhammad, Figh Wanita; Refleksi Kiai atas Wacana Agama dan Gender Jakarta: PT LKiS Pelangi Aksara, 2001.

Khaeron Sirin, Perkawinan Mazhab Indonesia : Pergulatan Antara Negara, Agama dan Perempuan, Yogyakarta: Deepublish, 2018.

Khaldun, 'Abd al-Rahman Ibn, Muqaddimah, Mesir: Maktabah Mustafa Muhammad, t.t.

Khaled M, Abou El Fadl, Atas Nama Tuhan: Dari Fikih Otoriter ke Fikih Otoritatif, terj. R. Cecep Lukman Yasin, Jakarta: PT Serambi Ilmu Semesta, 2003.

Khatimah, Najmah Sa'idah Husnul Khatimah, Revisi Politik Perempuan (Bercermin pada Shahabiyah Ra), Jakarta: Idea Pustaka, 2003.

Leonard Grob, Riffat Hasan dan Hain Gordon, “Jihad fi Sabilillah, "Women's Faith Journey From Struggel to Struggle, dalam buku Women's and Men's Liberation, USA: Greenwood Press, 1993.

M. Laily Mansur, Ajaran dan Teladan Pada Sufi, Jakarta: PT. Raja Grafindo Persada, 1996.

M.N. Ibad, Kekuatan Perempuan dalam Perjuangan Gus Dur-Gus Miek, Yogyakarta: Pustaka Pesantren, 2011.

Mahmûd Syaltût, Min Taujîhât al-Islâm (Kairo: al-Idârah al-Âmah li al-Azhar, 1959.

Mangunhardjana, A. M., Kepemimpinan, Yogyakarta: Kanisius, 1976.

Martoprawiro, Soedarsono, Kepemimpinan, Jakarta: Mutiara, 1980.

Masturi Irham dan Asmu'i Taman, 60 Biografi Ulama Salaf, Jakarta: Pustaka al-Kautsar, 2006.

Moelong, Lexy J., Metode Penelitian Kaulitatif, Bandung: PT Remaja Rodakarya, 2017.

Moenawir Khalil, Biografi Empat Serangkai Imam Madzhab, (Jakarta: Bulan Ibntang, tt.

Muhammad Abu Zahrah, Al-Syafi'i: Hayatuh wa 'Ashruh- 'Arauh wa Fiqhuh, Kairo: Dar alFikr al-'Arabi, 1978.

Mulia, Siti Musdah dan Anik Farida, Perempuan dan Politik, Jakarta: Gramedia Pustaka Utama, 2005.

Mulia, Siti Musdah, Menuju Kemandirian Politik Perempuan, (Yogyakarta: Kibar Press, 2007.

Murtadha Muthahhari, Filsafat Perempuan dalam Islam: Hak Perempuan dan Relevansi Etika Sosial, T.tp: Abbaz Production, t.t.

Muslimin Zuhdi, Tetaplah Beribnar Sekalipun Langit Runtuh, Ponorogo: Kuwaiz, 2009.

Nasaruddin Umar, Kodrat Perempuan dalam al-Qur'an, Jakarta: Fikahati Aneka, 2000.

Nasra M. Shah (ed), Pakistani Women A Socio-Economic and Demographic Profile, Islamabad: Pakistan Institute of Development Economics, t. t.

Nasution, Harun, Filsafat dan Mistisme Dalam Islam, Jakarta: Bulan Bintang, 1987.

Nazir, Moh., Metodelogi Penelitian, Bogor: Penerbit Ghalia Indonesia, 2011.

Rahman, Fazlur, Major Themes of The Qur'ân, Chicago: The University of Chicago Press, 2009.

Ranoh, Ayub, Kepemimpinan Kharismatis: Tinjauan Teologis-Etis atas Kepemimpinan Kharismatis Sukarno, Jakarta: PT BPK Gunung Mulia, 2006. 
Rivai, Veithzal dan Arvian Arifin, Islamic Leadership: Membangun Super Leadership Melalui Kecerdasan Spiritual, Jakarta: Bumi Aksara, 2009.

Rivai, Veitzal, Kiat Memimpin Abad ke-21, Jakarta: Raja Grafindo, 2004.

Rusn, Abidin ibnu, Pemikiran Al Ghazali Tentang Pendidikan, Yogyakarta: Pustaka Pelajar, 1998.

S. Manzoor Rizvi, The Sunshine Book: A Guide For Teens and Youth, (USA: Message of Peace, 2014.

Sagala, Saiful, Pendekatan dan Model Kepemimpinan, Jakarta: PRENADAMEDIA GROUP, 2018.

Salman ibn Fadh al-Audah, F̄̄ Hiwar Hādi,ma`a Muhammad Al-Ghazāli, Haran Burairah, $1409 \mathrm{H}$.

Sayyid Qutb, Tafsir fi Zhilalil Qur'an: Di Bawah Nauangan al-Qur'an, terj. As'ad Yasin, dkk, Jakarta: Gema Insani Press, 2003.

Shawqi Abu Khalil, Atlas on The Prophet's Biography: Places, Nation, Landmarks, Riyadh: Darussalam, 2004.

Shihab, Quraisy, Wawasan Al Qur'an, Bandung: Mizan, 1998.

Singaruimbun, Masri dan Sofian Efendi, Metode Penelitian Survai, Jakarta : LP3ES, 2011.

Syarifuddin Jurdi, Kekuatan-kekuatan Politik Indonesia: Kontestasi Ideologi dan Kepentingan, Jakarta: Kencana, 2016.

Thomas Patrick Hughes, A Dictionary of Islam, New Delhi: Hauz Khas Village, 2001.

Umar, Nasaruddin, Teologi Jender: Mitos dan Teks Kitab Suci, Jakarta: Pustaka Cicero, t.t.

Wahbbah al-Zuhailî, Al-Tafsîr al-Wajîz 'alâ Hâmisy al-Qur'ân al-'Aż̂m, Suriah: Dâr al-Fikr, t.t.

Wijono, Sutarto, Kepemimpinan dalam Perspektif Organisasi, Jakarta: PRENADAMEDIA GROUP, 2018.

Wolfson, Harry Austryn, The Philosophy Kalâm, Harvard: Harvard University Press, 1976.

Yaacov Lev, State and Society in Fatimid Egypt, Leiden: E.J. Brill, 1991.

Yucki Prihadi, Keagungan Tiga Wanita Pilar Islam: Meneladani Siti Hawa, Siti Hajar dan Siti Khadijah, Jakarta: PT Elex Media Komputindo, 2013.

Yusep Rafiqi, Belajar Hidup dari Allah: 7 Etos Suci Al-Fatihah untuk Kebahagiaan DuniaAkhirat, Jakarta: PT Elex Media Komputindo, 2015.

Yusuf al Qardhawi, Meluruskan Dikotomi Agama \& Politik "Bantahan Tuntas Terhadap Sekularisme dan Liberalisme", Jakarta, Pustaka al-Kautsar, 2008.

Yûsuf al-Qardlâwî, Fiqih Daulah Perspektif al-Qur`an dan Sunnah, Jakarta: Pustaka alKautsar, 1997. .

Zainuddin, Muhtadi dan Abd Mustaqim, Studi Kepemimpinan Islam: Telaah Normatif dan Historis, Semarang: Putra Mediatama Press, 2005.

Zaitunah Subhan, Al-Qur'an dan Perempuan: Menuju Kesetaraan Gender dalam Penafsiran, Jakarta: Prenadamedia Group, 2015.

Zamanin, 'Abû 'Abdullâh ibn 'Abdullâh ibn 'Abû, Tafsîr al-Qur'ân al-'Azhîm, T.tp: AlFârûq al-Hadîtsah, 2002.

\section{Jurnal}

Ariza Abdullah, et al. "Menelusuri Daya Tahan Wanita Islam Generasi Awal Bagi Mencapai Keunggulan Melalui Analisis Wacana Hadis Nabawi." Sains Humanika 9.1-5 (2017).

Ilahi, Kurnia, "Perempuan dalam Islam dan Kristen Katolik (Sebuah Telaah Teologi Kerukunan), Purari, Vol. 2. No. 1, Juni 2007. 
Iqbal, "PERANAN KHADIJAH TERHADAP PENYEBARAN AGAMA ISLAM DI MEKAH." Rihlah Jurnal Sejarah dan Kebudayaan 5.1 (2017).

Kasmawati, "Gender dalam Perspektif Islam”, Sipakalebbi', Vol. 1, No. 1, Mei 2013.

Samsul Nizar. "PENDIDIKAN PEREMPUAN: Kajian Sejarah yang Terabaikan." Lentera Pendidikan: Jurnal Ilmu Tarbiyah dan Keguruan 11.1 (2017).

Siswa, Imran, "Hak Asasi Manusia dalam Piagam Madinah serta Prinsip-prinsip Konstitusi Madinah”, Mahkamah, Vol. 2, No. 2 Oktober 2010. 